\title{
Immediate Closures and Violations Identified During Routine Inspections of Public Aquatic Facilities - Network for Aquatic Facility Inspection Surveillance, Five States, 2013
}

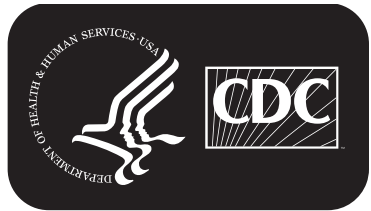




\section{CONTENTS}

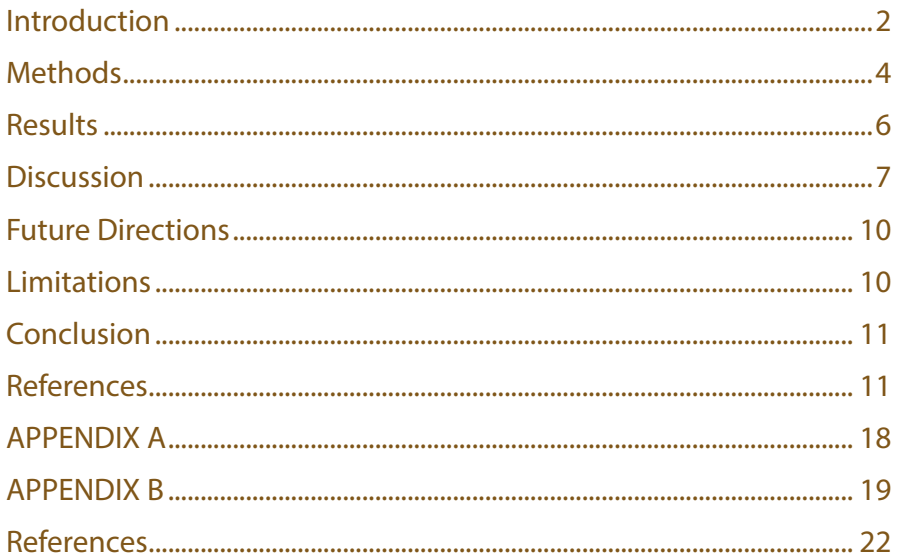

The MMWR series of publications is published by the Center for Surveillance, Epidemiology, and Laboratory Services, Centers for Disease Control and Prevention (CDC), U.S. Department of Health and Human Services, Atlanta, GA 30329-4027.

Suggested citation: [Author names; first three, then et al., if more than six.] [Title]. MMWR Surveill Summ 2016;65(No. SS-\#):[inclusive page numbers].

\section{Centers for Disease Control and Prevention}

Thomas R. Frieden, MD, MPH, Director

Harold W. Jaffe, MD, MA, Associate Director for Science

Joanne Cono, MD, ScM, Director, Office of Science Quality

Chesley L. Richards, MD, MPH, Deputy Director for Public Health Scientific Services

Michael F. Iademarco, MD, MPH, Director, Center for Surveillance, Epidemiology, and Laboratory Services

Sonja A. Rasmussen, MD, MS, Editor-in-Chief

\section{MMWR Editorial and Production Staff (Serials)}

Charlotte K. Kent, PhD, MPH, Executive Editor Christine G. Casey, MD, Editor

Teresa F. Rutledge, Managing Editor

David C. Johnson, Lead Technical Writer-Editor Jeffrey D. Sokolow, MA, Project Editor
Martha F. Boyd, Lead Visual Information Specialist Maureen A. Leahy, Julia C. Martinroe, Stephen R. Spriggs, Moua Yang, Tong Yang, Visual Information Specialists

Quang M. Doan, MBA, Phyllis H. King, Terraye M. Starr, Information Technology Specialists
MMWR Editorial Board

Timothy F. Jones, MD, Chairman Matthew L. Boulton, MD, MPH Virginia A. Caine, MD

Katherine Lyon Daniel, $\mathrm{PhD}$ Jonathan E. Fielding, MD, MPH, MBA David W. Fleming, MD
William E. Halperin, MD, DrPH, MPH

King K. Holmes, MD, PhD

Robin Ikeda, MD, MPH

Rima F. Khabbaz, MD

Phyllis Meadows, PhD, MSN, RN Jewel Mullen, MD, MPH, MPA
Jeff Niederdeppe, PhD

Patricia Quinlisk, MD, MPH

Patrick L. Remington, MD, MPH Carlos Roig, MS, MA

William L. Roper, MD, MPH

William Schaffner, MD 


\title{
Immediate Closures and Violations Identified During Routine Inspections of Public Aquatic Facilities - Network for Aquatic Facility Inspection Surveillance, Five States, 2013
}

\author{
Michele C. Hlavsa, $\mathrm{MPH}^{1}$, Taryn R. Gerth, $\mathrm{MPH}^{1}$, Sarah A. Collier, MPH ${ }^{1}$, Elizabeth L. Dunbar, MPH ${ }^{1,2}$, Gouthami Rao, MPH ${ }^{1}$, Gregory \\ Epperson $^{3}$, Becky Bramlett ${ }^{4}$, David F. Ludwig, MPH${ }^{5}$, Diana Gomez, MPH ${ }^{6}$, Monty M. Stansbury ${ }^{6}$, Freeman Miller ${ }^{6}$, Jeffrey Warren ${ }^{7}$, Jim Nichol ${ }^{8}$, \\ Harry Bowman ${ }^{8 *}$, Bao-An Huynh, MPH ${ }^{9}$, Kara M. Loewe ${ }^{10}$, Bob Vincent ${ }^{10}$, Amanda L. Tarrier, MPH ${ }^{11}$, Timothy Shay ${ }^{11}$, Robert Wright ${ }^{12}$, \\ Allison C. Brown, $\mathrm{PhD}^{1}$, Jasen M. Kunz, MPH${ }^{13}$, Kathleen E. Fullerton, MPH${ }^{1}$, James R. Cope, $\mathrm{PhD}^{14}$, Michael J. Beach, $\mathrm{PhD}^{1}$ \\ ${ }^{1}$ Division of Foodborne, Waterborne, and Environmental Diseases, National Center for Emerging and Zoonotic Infections Diseases, CDC \\ ${ }^{2}$ CDC/Association of Schools of Public Health Fellow, CDC \\ ${ }^{3}$ Maricopa County Environmental Services Department, Arizona \\ ${ }^{4}$ Mohave County Department of Public Health, Environmental Health Division, Arizona \\ 5 Pima County Health Department, Arizona \\ ${ }^{6}$ Yuma County Environmental Health Services Division, Arizona \\ ${ }^{7}$ Orange County Environmental Health Division, California \\ ${ }^{8}$ San Bernardino County Division of Environmental Health Services, California \\ ${ }^{9}$ San Diego County Department of Environmental Health, California \\ 10 Florida Department of Health \\ ${ }^{11}$ New York State Department of Health \\ 12 Division of Environmental Health Services, Department of Health and Human Services, Austin, Texas \\ ${ }^{13}$ Division of Emergency and Environmental Health Services, National Center for Environmental Health, CDC \\ ${ }^{14}$ Division of Global Health Protection, Center for Global Health, CDC
}

\begin{abstract}
Problem/Condition: Aquatic facility-associated illness and injury in the United States include disease outbreaks of infectious or chemical etiology, drowning, and pool chemical-associated health events (e.g., respiratory distress or burns). These conditions affect persons of all ages, particularly young children, and can lead to disability or even death. A total of 650 aquatic facility-associated outbreaks have been reported to CDC for 1978-2012. During 1999-2010, drownings resulted in approximately 4,000 deaths each year in the United States. Drowning is the leading cause of injury deaths in children aged 1-4 years, and approximately half of fatal drownings in this age group occur in swimming pools. During 2003-2012, pool chemical-associated health events resulted in an estimated 3,000-5,000 visits to U.S. emergency departments each year, and approximately half of the patients were aged $<18$ years. In August 2014, CDC released the Model Aquatic Health Code (MAHC), national guidance that can be adopted voluntarily by state and local jurisdictions to minimize the risk for illness and injury at public aquatic facilities.
\end{abstract}

\section{Reporting Period Covered: 2013.}

Description of System: The Network for Aquatic Facility Inspection Surveillance (NAFIS) was established by CDC in 2013. NAFIS receives aquatic facility inspection data collected by environmental health practitioners when assessing the operation and maintenance of public aquatic facilities. This report presents inspection data that were reported by 16 public health agencies in five states (Arizona, California, Florida, New York, and Texas) and focuses on 15 MAHC elements deemed critical to minimizing the risk for illness and injury associated with aquatic facilities (e.g., disinfection to prevent transmission of infectious pathogens, safety equipment to rescue distressed bathers, and pool chemical safety). Although these data (the first and most recent that are available) are not nationally representative, 15.7\% of the estimated 309,000 U.S. public aquatic venues are located in the 16 reporting jurisdictions.

Results: During 2013, environmental health practitioners in the 16 reporting NAFIS jurisdictions conducted 84,187 routine inspections of 48,632 public aquatic venues. Of the 84,187 of routine inspection records for individual aquatic venues, $78.5 \%(66,098)$ included data on immediate closure; $12.3 \%(8,118)$ of routine inspections resulted in immediate closure because of at least one identified violation that represented a serious threat to public health. Disinfectant concentration violations were identified during $11.9 \%(7,662 / 64,580)$ of routine inspections, representing risk for aquatic facility-associated outbreaks of infectious etiology. Safety equipment violations were identified during $12.7 \%(7,845 / 61,648)$ of routine inspections, representing risk for drowning. Pool chemical safety violations were identified

Corresponding author: Michele Hlavsa, Division of Foodborne, Waterborne, and Environmental Diseases, National Center for Emerging and Zoonotic Infections Diseases, CDC. E-mail: acz3@cdc.gov. Telephone: 404-718-4695. during $4.6 \%(471 / 10,264)$ of routine inspections, representing risk for pool chemical-associated health events.

${ }^{*}$ Deceased. 
Interpretation: Routine inspections frequently resulted in immediate closure and identified violations of inspection items corresponding to $15 \mathrm{MAHC}$ elements critical to protecting public health, highlighting the need to improve operation and maintenance of U.S. public aquatic facilities. These findings also underscore the public health function that code enforcement, conducted by environmental health practitioners, has in preventing illness and injury at public aquatic facilities.

Public Health Action: Findings from the routine analyses of aquatic facility inspection data can inform program planning, implementation, and evaluation. At the state and local level, these inspection data can be used to identify aquatic facilities and venues in need of more frequent inspections and to select topics to cover in training for aquatic facility operators. At the national level, these data can be used to evaluate whether the adoption of MAHC elements minimizes the risk for aquatic facility-associated illness and injury. These findings also can be used to prioritize revisions or updates to the MAHC. To optimize the collection and analysis of aquatic facility inspection data and thus application of findings, environmental health practitioners and epidemiologists need to collaborate extensively to identify public aquatic facility code elements deemed critical to protecting public health and determine the best way to assess and document compliance during inspections.

\section{Introduction}

Illness and injury associated with aquatic facilities ${ }^{\dagger}$ in the United States include disease outbreaks of infectious or chemical etiology, drowning, and pool chemical ${ }^{\S}$-associated health events (e.g., respiratory distress or burns). These conditions affect persons of all ages, particularly young children, and can lead to disability or even death. Construction of public aquatic facilities for swimming, play, and relaxation increased in the United States throughout the 20th century as water treatment technology advanced (1). In 2009, swimming was the fourth most popular sports activity in the United States and the most popular among children aged $7-17$ years; an estimated $50,226,000$ persons aged $\geq 7$ years swam at least six times in 2009, translating to at least 301,356,000 swimming instances (2). Aquatic sector marketing data indicate that there were an estimated 309,000 public aquatic venues** throughout the United States in 2011 (3). Public aquatic facilities also have increased in size, accommodating tens of thousands of bathers per day, and have moved indoors, making swimming, play, and relaxation in aquatic venues possible year round instead of being limited to the warmer months. Moreover, with design innovations, aquatic venues have simultaneously evolved from being traditional rectangular pools to pools of various designs (e.g., interactive water play venues ${ }^{\dagger \dagger}$ ) and to include venues other than pools (e.g., hot tubs/spas).

\footnotetext{
$\dagger$ A glossary of the terms used in this report is provided (Appendix A).

$\S$ The term "pool chemical" is used to refer to any chemical used to maintain water quality or stop corrosion and scaling of equipment in any aquatic venue, not only pools.

9 This is an underestimate because it does not take into account swimming instances of children aged $0-6$ years, persons aged $\geq 7$ years who swam less than six times per year, or the seventh and subsequent swimming instances of persons aged $\geq 7$ years who swam more than six times per year.

** For terminology to be aligned with CDC's Model Aquatic Health Code (MAHC), the term "aquatic venue" has replaced the term "treated recreational water venue," which has been used historically by CDC in $M M W R$ reports and surveillance summaries.

†† For terminology to be aligned with CDC's MAHC, the term "interactive water play venue" has replaced the term "interactive fountain," which has been used historically by CDC in MMWR reports and surveillance summaries.
}

Water-based physical activity improves physical and mental health throughout life (4) and might be the only physical activity option for those with medical restrictions. However, participants in such activities are at risk for aquatic facility-associated illness and injury. The overriding public health goal is to maximize the health benefits of water-based physical activities while minimizing the risk for illness and injury. Surveillance data are used to characterize the epidemiology of illness and injury at aquatic facilities (i.e., estimate magnitude, document distribution, and track natural history) and inform and evaluate prevention efforts (5). Existing national surveillance systems monitor the following subcategories of aquatic facility-associated illnesses and injuries: aquatic facility-associated outbreaks, ${ }^{\$ \$}$ drownings, and pool chemical-associated health events.

\section{Existing National Surveillance Systems Monitoring Aquatic Facility-Associated IIIness and Injury}

Since 1978, CDC has tracked aquatic facility-associated outbreaks via the Waterborne Disease and Outbreak Surveillance System (WBDOSS) (http://www.cdc.gov/healthywater/ surveillance/rec-water-surveillance-reports.html). An aquatic facility-associated outbreak is defined as the occurrence of similar illness in two or more persons, epidemiologically linked by location and time of exposure to recreational water or to recreational water-associated chemicals volatilized or aerosolized into the air surrounding the water. During 1978-2012, a total of 650 aquatic facility-associated outbreaks were reported to CDC (Figure). Although these reported data likely represent

\footnotetext{
$\$ \$$ For terminology to be aligned with CDC's MAHC, the term "aquatic facilityassociated outbreaks" has replaced the term "treated recreational waterassociated outbreaks," which has been used historically by CDC in MMWR reports and surveillance summaries.
} 
only a fraction of outbreaks that occurred, 99 national outbreak data can be used to detect changes in the epidemiology of aquatic facility-associated outbreaks, including novel aquatic venues, emerging infectious pathogens, and the shift to indoor settings. For example, these data indicate that a spike in the incidence of outbreaks of Pseudomonas folliculitis associated with hot tubs/spas occurred in the early 1980s, when hot tubs/ spas became popular but before operation and maintenance standards could be established in jurisdictions across the United States. In 1988, the first U.S. aquatic facility-associated outbreak of cryptosporidiosis was detected $(6,7)$. Since then, the annual incidence of such reported outbreaks has increased substantially, and Cryptosporidium, the parasite that causes cryptosporidiosis, has emerged as the leading etiology of reported aquatic facilityassociated outbreaks because of its extreme chlorine tolerance (8). Moreover, a focal cryptosporidiosis outbreak associated with one aquatic facility can expand into a community-wide outbreak that is associated with hundreds of aquatic facilities, affects thousands of persons (disproportionately young children), and spreads to other additional settings (e.g., child

\footnotetext{
99 Many factors can present barriers to the detection, investigation, and reporting of outbreaks: 1) mild illness, 2) small outbreak size, 3) long incubation periods, 4) wide geographic dispersion of ill swimmers, 5) transient nature of contamination, 6) setting or venue of outbreak exposure (e.g., residential backyard pool), 7) lack of public health staff to investigate fully, 8) potential lack of communication between those who respond to outbreaks of chemical etiology (e.g., hazardous materials personnel) and those who usually report outbreaks (e.g., infectious disease epidemiologists), and 9) reporting requirements (8).
}

care facilities) (9). With the proliferation of indoor waterparks in recent years, $\mathrm{CDC}$ has increasingly received reports of aquatic facility-associated outbreaks involving indoor settings (8). The largest such outbreak to date, which occurred in Ohio in 2007, affected at least 665 persons and was caused by volatile disinfection by-products called chloramines (10). Dichloramine and trichloramine are created when chlorine oxidizes nitrogenous compounds (e.g., human waste products such as sweat and urine). Unlike monochloramine, which is commonly used to disinfect drinking water, these chloramines can cause ocular and respiratory tract irritation. Limiting the amounts of fresh air introduced and of chloramine-polluted air exhausted, particularly during colder months, increases these health effects.

Mortality data from CDC's National Vital Statistics System (NVSS) (http://www.cdc.gov/nchs/nvss.htm) for 1999-2010 indicate that approximately 4,000 persons die from drowning each year in the United States (11). Drowning is the leading cause of injury death in children aged 1-4 years; more than half of fatal drownings in this age group occur in a pool. Nonfatal drownings annually lead to an average of approximately 5,800 U.S. emergency department (ED) visits (2005-2009) (12). More than half of the patients are children aged $\leq 4$ years, and nearly two thirds of the nonfatal drownings in this age group occurred in pools. Half of nonfatal drownings require hospitalization and can result in severe brain damage, longterm mental and physical disabilities, and substantial health care costs.

FIGURE. Aquatic facility-associated outbreaks, by year — Waterborne Disease and Outbreak Surveillance System, United States, 1978-2012*

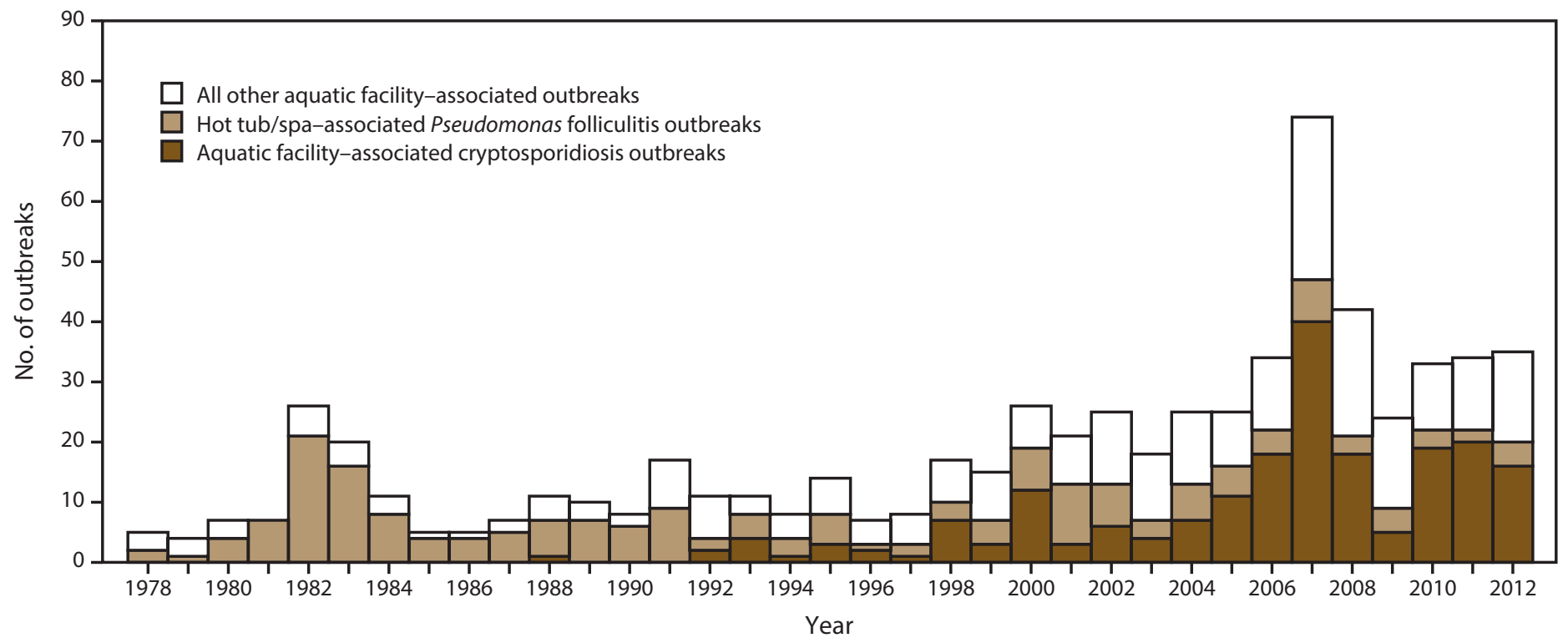

Source: Hlavsa MC, Roberts VA, Kahler AM, et al. Outbreaks of illness associated with recreational water-United States, 2011-2012. MMWR Morb Mortal Wkly Rep 2015;64:668-72.

* N =650 (203 aquatic facility-associated cryptosporidiosis outbreaks, 189 hot tub/spa-associated Pseudomonas folliculitis outbreaks, and 258 other aquatic facilityassociated outbreaks). 
In 2007, the New York State Department of Health (NYSDOH) asked CDC to monitor health events associated with pool chemicals (Doug Sackett, personal communication, 2007). Since then, CDC's WBDOSS has received additional reports from New York and from other states of outbreaks caused by exposure to toxic chlorine gas. Toxic chlorine gas can be generated when chlorine and acid, which is typically used to adjust $\mathrm{pH}$, are mixed by aquatics staff or in an aquatic venue's plumbing when there is inadequate water flow. Data from the U.S. Consumer Product Safety Commission's National Electronic Injury Surveillance System (NEISS) (http://www. cpsc.gov/en/Research--Statistics/NEISS-Injury-Data) for 2003-2012 indicate that pool chemical-associated health events annually lead to approximately 3,000-5,000 visits to U.S. EDs; almost half of the patients are aged $<18$ years $(13-15)$. The most frequent diagnosis is poisoning (predominantly stemming from inhalation of vapors, fumes, or gases rather than ingestion) followed by dermatitis or conjunctivitis caused by chemical splashes onto the skin or into the eyes, respectively. In addition, CDC's Sentinel Event Notification System for Occupational Risk data have been used to examine pool chemical-associated health events from an occupational health perspective (16), and data from ATSDR's Hazardous Substances Emergency Events Surveillance program ${ }^{* * *}$ have been used to examine health events resulting from chemical spills (17).

\section{The Model Aquatic Health Code and the Network for Aquatic Facility Inspection Surveillance}

During 2007-2014, CDC and NYSDOH led a national consortium of public health and aquatics sector experts to develop the Model Aquatic Health Code (MAHC), national guidance that can be voluntarily adopted by state and local jurisdictions to minimize the risk for illness and injury at public aquatic facilities. The development of the MAHC is described elsewhere (Appendix B). In August 2014, CDC released the first edition of the MAHC (http://www.cdc.gov/mahc/index. html), which covers a full range of issues pertaining to aquatic facilities, including their design, construction, operation, maintenance, and management. The penultimate draft of the MAHC enabled CDC to launch, in 2013, the Network for Aquatic Facility Inspection Surveillance (NAFIS), which established for the first time an ongoing multijurisdictional surveillance network for aquatic facility inspection data.

Data are needed so public health authorities can evaluate whether adoption of MAHC elements minimizes the risk for

\footnotetext{
*** This program is now known as the National Toxic Substance Incidents Program.
}

illness and injury at public aquatic facilities. However, decreases in the incidence of aquatic facility-associated outbreaks, drowning, and pool chemical-associated health events attributable to adoption of MAHC design and construction elements might not be detected by existing national surveillance systems for decades. Long periods of time are likely to elapse between the writing, enactment, implementation, and enforcement of MAHC elements in a given jurisdiction and across the United States. The time to adoption and the number, if any, of MAHC elements adopted will vary across jurisdictions. Most importantly, many design and operation elements apply only to newly constructed or substantially altered aquatic facilities.

Inspections of public aquatic facilities allow a real-time assessment of their operation and maintenance, and environmental health practitioners document their inspection findings using a standardized form. Analysis of inspection data can be used to examine immediate closures and violations (i.e., inspectionoutcome data) to estimate magnitude, document distribution, track natural history, and inform and evaluate prevention efforts (5). Because improper operation and maintenance represent risk for aquatic facility-associated illness and injury, NAFIS data can be used to evaluate whether adoption of MAHC elements minimizes risk for illness and injury at public aquatic facilities more immediately (i.e., within years of the release of the MAHC first edition) than existing national surveillance systems.

\section{Methods}

The primary objective of NAFIS is to enable public health authorities to evaluate whether adoption of MAHC elements minimizes the risk for illness and injury at public aquatic facilities. The secondary objective is to demonstrate the utility of inspection data and thus expand their use by state and local environmental health programs to monitor the operation and maintenance of public aquatic facilities and inform program planning, implementation, and evaluation.

Inspection of public aquatic facilities (e.g., forms used, items inspected, and inspection methods) varies across jurisdictions because individual state and local jurisdictions write, enact, implement, and enforce their own unique public health codes. Five states (Arizona, California, Florida, New York, and Texas) with the highest estimated counts of public aquatic venues were selected; $39.6 \%(122,412)$ of the estimated 309,000 U.S. public aquatic venues are located in these five states (3). CDC invited local jurisdictions (county or city) from these five states to participate in NAFIS. A total of 25 local jurisdictions agreed to report data annually to CDC, but only 16 reported 2013 data to NAFIS by September 2015 . 


\section{Catchment Area}

Public aquatic facility codes can vary among states and within states (i.e., counties and cities in the same state might have different codes). Florida and New York have statewide public aquatic facility codes; Arizona and California codes vary by county. CDC invited the five counties with the highest counts of public aquatic venues (as per state public health officials in each of the four respective states) to participate in NAFIS. If a county in a given state could not, the county with the sixth highest count of public aquatic venues in that state was invited. Texas public aquatic facility codes can vary within a county, and CDC invited the five most populous cities as determined by 2013 census data to participate in NAFIS (18). If one of these Texas cities could not, the sixth most populous Texas city was invited. The five counties with the highest counts of public aquatic venues in California and Florida, five of the six counties with the highest counts of public aquatic venues in Arizona and New York, and five of the six most populous Texas cities agreed to annually report data to NAFIS. By September 11, 2015, the publication cut-off date, $16(64 \%)$ jurisdictions reported 2013 data to NAFIS (Table 1). The remaining nine (36\%) jurisdictions did not report data because three jurisdictions were unable to access data, three were unable to extract data sets (i.e., all records) by the cut-off date, two did not have electronic data for 2013, and one did not respond.

\section{Data Source and Collection}

The launch of NAFIS began with the selection of elements for surveillance. CDC reviewed draft MAHC guidance before it was finalized and released in 2014 and identified approximately 50 MAHC illness and injury risk-minimizing elements that protect public health. Because of the variability in codes and inspection data collected, CDC limited NAFIS's initial list of MAHC elements for surveillance to the 15 elements deemed critical to minimizing the risk for aquatic facility-associated illness and injury (Table 2) and most likely to be included in inspections in these jurisdictions (Table 1). Identifying violations of inspection items corresponding to these 15 critical elements could result in immediate closure because these violations represent a serious threat to public health.

\section{Inspection of a Public Aquatic Facility}

An inspection of a public aquatic facility is an assessment of whether its operation and maintenance meet the standards set in the jurisdiction's public health code and provides a real-time snapshot of whether the facility is being operated and maintained in a way that minimizes risk for aquatic facility-associated illness and injury. There are three types of inspections: routine, complaint, and follow-up. Routine inspections are conducted one to three times per year (primarily during the warmer months) and typically result in the completion of an entire inspection form to document the findings of a full assessment of the operation and maintenance of a public aquatic facility. Complaint inspections are conducted in response to a specific complaint (e.g., from a bather). Follow-up inspections are conducted to ensure that violations that were identified during previous inspections and that resulted in immediate closure have been corrected before reopening. Environmental health practitioners conduct inspections of an entire public aquatic facility, and a separate inspection report or record documents the assessment of each aquatic venue within the public aquatic facility. If an item is inspected and found not to be in compliance with the code, a violation has been identified; violations represent risk for aquatic facility-associated illness and injury. Ideally, the inspection items with the greatest impact on public health are prioritized and identification of corresponding violations could result in immediate closure. Priority inspection items include measuring free available chlorine and $\mathrm{pH}$ to ascertain whether they are within the required range; confirming that the fencing, walls, and self-closing and self-latching gates and doors are in good repair; and checking that the pool chemicals have labels required by either the Occupational Safety and Health Administration or the Environmental Protection Agency and are safely and securely stored.

\section{Data Standardization and Analysis}

Initially, jurisdictions sent their inspection forms and public aquatic facility codes to CDC for review. CDC sent back, for discussion, a proposed list of inspection items that corresponded to the 15 critical illness and injury risk-minimizing MAHC elements. These 15 MAHC elements were sorted into four categories: 1) aquatic facility-associated illness prevention elements, 2) drowning and entrapment prevention elements, 3) prevention elements for pool chemical-associated health events and other nondrowning and nonentrapment injuries, and 4) general health and safety elements. A jurisdiction's list of elements was not considered finalized until it was approved by the jurisdiction. Because codes, and thus, inspection forms, items inspected, and even how the same aspect of public aquatic facility operation and maintenance is inspected vary across jurisdictions, identified violations were specific to each jurisdiction and not to an overall standard.

Reporting jurisdictions submitted an electronic data set with their 2013 aquatic facility inspection data. Only data from routine inspections were analyzed because unlike routine inspections, complaint and follow-up inspections typically 
focus on a subset of inspection items and do not result in a full assessment of the operation and maintenance of a public aquatic facility (i.e., the entire inspection form would not be completed to document inspection findings). Including data collected during complaint and follow-up inspections, in the analysis, could result in underestimates of the proportions of inspections that resulted in immediate closure or that identified violations.

SAS 9.3 (SAS Institute Inc., Cary, North Carolina) was used to reformat, standardize, and analyze data sets. Data sets were reformatted, as needed. For example, a data set, in which each record was an individual identified violation, was restructured into a data set, in which each record was for an inspection and included data on compliance status of multiple inspection items. If a violation was not documented for a specific inspection item, the inspection item was assumed to have been found to be in compliance (i.e., not in violation). Variable names and their respective values were standardized across data sets. Previous analysis of aquatic facility inspection data (19) indicated that these data sets do not typically include data on aquatic facility setting (e.g., apartment/condominium, hotel/motel, and waterpark). Therefore, CDC developed an algorithm to identify aquatic facility setting, using aquatic facility name. The setting algorithm used the following terms to create the setting variable: 1) "apt," "apartment," "condo," "HOA," "townhouse," "townhome," and "home" for the category apartment/condominium; 2) "campground" and "camp" for the category campground (e.g., campsite)/camp (e.g., summer camp or day camp); 3) "child care," "day care," "childcare," and "daycare" for the category childcare; 4) "hospital," "rehab," "outpatient," "medical," "nursing," and "assisted living facility" for the category hospital; 5) "hotel," "motel," "inn," "suites," "extended stay," "bed and breakfast," "hostel," and the names of large hospitality industry chains for the category hotel/motel; 6) "fitness," "gym," "country club," "athletic," "swim school," "YMCA," and "sports center" for the category membership club; 7) "community" and "municipal" for the category municipal; 8) "university" and "college" for the category school/university; and 9) "waterpark" and "water park" for the category waterpark.

The setting algorithm was coded so that once the setting was classified by SAS, subsequent terms in the algorithm did not trigger a reclassification of the setting. After assigning a setting variable, aquatic facility name was deleted. A summary of findings was reported to each jurisdiction; data were not considered finalized until approved by the jurisdiction. Subsequently, the 16 individual data sets were then concatenated into one final data set.

Analyses included counts of routine inspections; median and range of counts of any violations identified per routine inspection; and proportions of routine inspections that identified at least one violation, resulted in immediate closure, or identified violations when inspecting items corresponding to the 15 critical illness and injury risk-minimizing MAHC elements. Analyses were conducted of the data overall and stratified by aquatic venue type (e.g., pool and hot tub/spa) and pool category (e.g., wading pool and interactive water play venue). The denominators in this report vary because of differences in the number of jurisdictions contributing inspection data (Table 2).

\section{Results}

Among the 16 NAFIS jurisdictions that provided data, nine $(56 \%)$ reported aquatic facility inspection data that included both immediate closure and violation data, five (31\%) reported only violation data, and two (13\%) reported only immediate closure data. One (6\%) jurisdiction included data that identified violation(s) leading to immediate closure. The number of jurisdictions contributing data to examine each critical element varied substantially, with no single jurisdiction contributing data to examine all 15 critical elements (Table 2). Fifteen (94\%) of 16 data sets included data on aquatic venue type, and $12(75 \%)$ of 16 included data on pool category However, only one $(6 \%)$ of 16 included data on aquatic facility setting; almost all pool $(99.5 \%[55,622 / 55,913])$ and hot tub/spa $(99.1 \%$ $[20,259 / 20,449])$ inspection records were missing data on aquatic facility setting. Use of the setting algorithm increased the number of inspection records with setting data; however, after the setting algorithm was run, $75.6 \%(42,249 / 55,913)$ of pool and $84.2 \%(17,213 / 20,449)$ of hot tub/spa inspection records still were missing aquatic facility setting data, thus no analyses stratified by setting were conducted.

During 2013, environmental health practitioners in the 16 NAFIS jurisdictions that reported data to CDC conducted 84,187 routine inspections of 48,632 public aquatic venues (Table 1). This corresponds to $15.7 \%$ of the estimated 309,000 venues in the United States. More than three quarters (78.9\% $[50,974 / 64,580])$ of routine aquatic venue inspections identified at least one violation. The median number of violations identified per inspection was two (range: 0-21). Of the 84,187 routine inspection records, $78.5 \%(66,098)$ included data on immediate closure; $12.3 \%(8,118)$ of routine inspections resulted in immediate closure (Table 3 ). The most frequently reported violations representing risk for aquatic facility-associated illness were disinfectant concentration (11.9\% [7,662/64,580]), pH (14.9\% [9,236/62,141]), and automated chemical feeder $(5.2 \%[3,031 / 57,967])$ violations. The most frequently reported violations representing risk for drowning were enclosure (e.g., fence) $(5.1 \%[3,303 / 64,580])$ and safety equipment $(12.7 \%[7,845 / 61,648])$ violations. 
Of the total 84,187 routine inspections, 55,913 (66.4\%) were of public pools. Of 43,636 routine pool inspections, $11.8 \%(5,139)$ resulted in immediate closure. Disinfectant concentration $(9.2 \%$ $[3,927 / 42,891]), \mathrm{pH}(12.4 \%[5,017 / 40,533])$, and automated chemical feeder $(6.2 \%[2,378 / 38,401])$ violations were the most frequently reported violations representing risk for aquatic facility-associated illness. Enclosure (5.7\% [2,449/42,891]) and safety equipment $(16.6 \%[6,689 / 40,231])$ violations were the most frequently reported violations representing risk for drowning. Violations representing risk for pool chemicalassociated health events (i.e., labeling, storage, or security of pool chemicals) were identified during $18.1 \%(427 / 2,358)$ of routine pool inspections.

Of the total 84,187 routine inspections, 20,449 (24.3\%) were of public hot tubs/spas. Of 14,637 routine hot tub/spa inspections, $15.1 \%(2,217)$ resulted in immediate closure. The most frequently reported violations identified during inspections of hot tubs/spas were disinfectant concentration (19.2\% [2,663/13,864]), pH (27.5\% [3,789/13,783]), pool chemical safety $(9.9 \%[8 / 81])$, and water temperature $(7.5 \%$ $[1,037 / 13,783])$.

By pool category, $>95 \%(95.8 \%[53,537 / 55,913])$ of inspections were of pools, $2.9 \%(1,606)$ of wading pools, $0.1 \%$ (69) of interactive water play venues, and $1.3 \%$ (701) of other (Table 4). Because $>95 \%$ of pool inspections were of "pools," their inspection findings and those of "pools," when the data are analyzed by aquatic venue type (e.g., pool and hot tub/spa), were nearly identical (Table 3). Of 948 routine inspections of wading pools, $21.6 \%$ (205) resulted in immediate closure (Table 4). The most frequently reported violations all represented risk for aquatic facility-associated illness: disinfectant concentration (19.2\% [303/1,581]), $\mathrm{pH}$ $(26.0 \%$ [411/1,581]), and automated chemical feeder $(6.1 \%$ $[94 / 1,539])$. Of 66 routine inspections of interactive water play venues, $12.1 \%$ (eight) resulted in immediate closure. As with wading pools, the most frequently reported violations all represented risk for aquatic facility-associated illness: disinfectant concentration (10.1\% [7/69]), $\mathrm{pH}(6.1 \%$ [4/66]), or automated chemical feeder $(5.8 \%$ [4/69]).

\section{Discussion}

This report is the first to summarize data from NAFIS; $15.7 \%$ of the estimated 309,000 U.S. public aquatic venues are located in the 16 reporting jurisdictions. The findings of this report underscore the need to improve the operation and maintenance of U.S. public aquatic facilities to prevent illness and injury, as more than three quarters $(78.9 \%)$ of routine inspections of public aquatic venues identified at least one violation. Multiple reports have previously examined data collected during inspections of U.S. public aquatic facilities with similar results, including analyses of 1961-1963 data from DuPage County, Illinois (20), 1999-2007 data from Plano, Texas (21), and 2005-2006 data from Nebraska (22). Three additional reports examined data collected during routine inspections of public aquatic facilities conducted in 2002 and 2008 in multiple jurisdictions across the United States (Table 5) $(19,23,24)$. All of these reports also found that violations of public health codes are identified frequently and immediate closures of public aquatic venues frequently occur.

Of note, $12.3 \%$ of routine inspections $(11.8 \%$ of pools and $15.1 \%$ of hot tubs/spas) resulted in immediate closure and violations of inspection items that corresponded to the 15 critical illness and injury risk-minimizing MAHC elements were identified frequently (Table 3) (Table 4). These findings underscore the public health function that code enforcement, conducted by environmental health practitioners, plays in preventing illness and injury at public aquatic facilities. During inspections, environmental health practitioners can serve as illness-and-injury-prevention advisors to aquatic facility operators. Immediate closures and identified violations offer an opportunity to educate operators about how to properly operate and maintain aquatic facilities and why these measures are necessary, to prevent repeated violations of a given operation or maintenance standard in public aquatic facility codes. Currently, only $68 \%$ of U.S. local public health agencies regulate, inspect, or license public aquatic facilities (25).

\section{Minimizing Risk for Aquatic Facility-Associated Outbreaks of Infectious Etiology}

In aquatic facilities, halogenation (e.g., chlorination or bromination) is the primary barrier to the transmission of infectious pathogens; proper $\mathrm{pH}$ ensures that the more active form of the halogen is available to inactivate infectious pathogens, and the automated chemical feeder delivers the halogen and $\mathrm{pH}$-adjusting chemical. ${ }^{\dagger \dagger}$ Outbreaks of acute gastrointestinal illness caused by halogen-susceptible pathogens do not occur unless the disinfectant concentration is inadequate; $\mathrm{pH}$ is improper; the automated chemical feeder is in poor condition or inoperable; or an operator error has occurred. Environmental health practitioners in the 16 reporting NAFIS jurisdictions identified disinfectant concentration, $\mathrm{pH}$, and automated chemical feeder violations during $11.9 \%, 14.9 \%$, and $5.2 \%$ of all inspections, respectively. These findings are corroborated by national data on outbreaks

\footnotetext{
ti† The amount of the more active form of the halogen available for disinfection is highly dependent on the $\mathrm{pH}$, substantially decreasing with increasing $\mathrm{pH}$. For example, hypochlorous acid, or $\mathrm{HOCl}$, is $96 \%$ at $\mathrm{pH} 6.0,72 \%$ at $\mathrm{pH} 7.0$, $48 \%$ at 7.5 , and $22 \%$ at $\mathrm{pH} 8.0$.
} 
of infectious etiology; during 2003-2012, halogen-susceptible pathogens caused $15.2-20.2 \%$ of aquatic facility-associated outbreaks of acute gastrointestinal illness. ${ }^{\$ S \$}$ Transmission of halogen-susceptible infectious pathogens (e.g., E. coli O157:H7 or Shigella spp.) can be prevented at MAHC-recommended disinfectant concentrations ( $1 \mathrm{ppm}$ minimum free available chlorine [MAHC 5.7.3.1.1.299] or $3 \mathrm{ppm}$ minimum free available bromine [MAHC 5.7.3.1.2.2]) at $\mathrm{pH} 7.2-7.8$ (MAHC 5.7.3.4.1). To minimize the incidence of disinfectant concentration and $\mathrm{pH}$ violations, aquatic facility operators (MAHC 6.3.1.1) should complete a training course (MAHC 6.1.1.1) $(22,26)$ that covers water disinfection and chemistry, mechanical systems (including automated chemical feeders), and other risk management strategies (MAHC 6.1.2).

Disinfectant concentration and $\mathrm{pH}$ violations were frequently documented at wading pools and interactive water play venues. Both of these aquatic venue types have features that make it more difficult to maintain halogen levels: wading pools are typically shallow, which facilitates halogen depletion by the sun's ultraviolet light, and interactive water play venues typically aerosolize the water, which depletes halogens. Wading pools and interactive water play venues are designed and intended for young children. Young children are more likely to experience acute gastrointestinal illnesses, such as cryptosporidiosis (caused by the extremely halogen-tolerant Cryptosporidium) (27-29), and are more likely to contaminate the water because they either are incontinent or have inadequate toileting and hygiene skills. Contamination can occur via direct release of formed or diarrheal feces (30), or as much as 10 grams of fecal material can rinse off a young child's perianal surface and into the water (31). Furthermore, swim diapers do not prevent feces, urine, or infectious pathogens from contaminating the water (32); and oxidation of organic or nitrogenous compounds (e.g., feces and urine) released or rinsed into the water deplete the halogen. In addition, young children typically ingest more recreational water than adults (33), putting them at increased risk for infection if pathogens are present. Consequently, maintaining proper disinfectant concentration and $\mathrm{pH}$, combined with effective control of the automated chemical feeder, is particularly critical in these aquatic venues. The MAHC classifies wading pools and interactive water play venues as "increased-risk aquatic venues" and recommends all such newly constructed or substantially altered aquatic venues include secondary disinfection systems

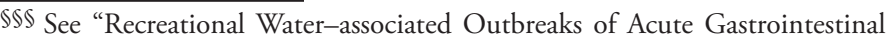
Illness (AGI), by Type of Exposure and Etiology — United States, 20032012" at http://www.cdc.gov/healthywater/surveillance/recreational/20112012-figures.html\#acuteGI-2003.

999 For reference purposes, MAHC elements that could minimize risk for aquatic facility-associated illness and injury and are discussed in this report are followed by the specific section number that covers that element.
}

(e.g., ultraviolet light or ozone [MAHC 4.7.3.3]) to achieve at least 3- $\log _{10}(99.9 \%)$ inactivation of Cryptosporidium.

Disinfectant concentration and $\mathrm{pH}$ violations were also frequently documented at hot tubs/spas. Maintaining adequate disinfectant concentration in hot tubs/spas can be particularly difficult, because the halogen can be depleted by both the higher water temperatures and aerosolization of water by jets. Moreover, thermophilic infectious pathogens, such as Pseudomonas aeruginosa and Legionella spp., can colonize and amplify in hot tubs/spas in which the disinfectant concentration is inadequately maintained $(34,35)$, leading to biofilm build-up that can protect these pathogens from disinfectants, even when adequate disinfectant concentration is maintained (36). During 2003-2012, Pseudomonas aeruginosa and Legionella spp. were confirmed or suspected to have caused 77 hot tub-/spa-associated outbreaks $(8,15,37-39)$. To increase the likelihood that adequate disinfectant concentration is maintained, facility operators should ensure that hot tubs/ spas have higher minimum disinfectant concentrations (3 ppm minimum free available chlorine [MAHC 5.7.3.1.1.2.3] or 4 ppm minimum free available bromine [MAHC 5.7.3.1.2.2]) than other aquatic venues. In addition, because cyanuric acid (which prevents halogen depletion by the sun's ultraviolet light) increases inactivation times of infectious pathogens (40-43), cyanuric acid should not be used in hot tubs/spas (MAHC 5.7.3.1.3.1). Debris and organic materials (which deplete halogens) and biofilm should be removed from the water and accessible surfaces of hot tubs/spas (MAHC 5.6.10.6.1) and there should be more frequent draining and cleaning of hot tubs/spas than other aquatic venues (MAHC 5.12.7.2). Finally, aquatic facility operators or responsible supervisors should conduct routine checks, in part to ensure biofilm has been removed from accessible surfaces, prior to facility opening (MAHC 6.4.1.3.1).

\section{Minimizing Risk for Drowning, Pool Chemical- Associated Health Events, and Other Injuries}

Maintaining enclosures (e.g., fencing, walls, and self-closing and self-latching gates and doors) (44) and safety equipment (e.g., hook or ring) at aquatic facilities minimizes the risk for drowning. Violations of these safety measures were documented by environmental health practitioners during $5.7 \%$ and $16.6 \%$, respectively, of routine pool inspections. Enclosures should be maintained at all times (MAHC 5.6.10.5.1) and newly constructed or substantially altered aquatic facilities should have 6-foot fences (MAHC 4.8.6.2.4.2) and fencing mesh with no greater than a 1.75 -inch opening to minimize scalability by young children (MAHC 4.8.6.2.1.2). Routine checks to ensure safety equipment is in place and in good repair should be conducted prior to facility opening (MAHC 6.4.1.3.1); 
if all required equipment is not present, the venue should be immediately closed (MAHC 6.6.3.1). Bather surveillance by trained lifeguards is another strategy to minimize the risk for drowning, but drowning can occur even in the presence of lifeguards (45). Lifeguard staffing should include clear and unobstructed zones of surveillance, and lifeguard staffing numbers should be based on the number of zones needed to have $100 \%$ unobstructed vision of the entire aquatic venue (MAHC 6.3.3.1.1, 6.3.3.1.2, and 6.3.3.1.3). To help minimize the risk for main drain-associated entrapment, ${ }^{* * * *}$ aquatic facility operator training should include the requirements of the Virginia Graeme Baker Pool and Spa Safety Act (MAHC 6.1.2.1.4.7).

Risk for pool chemical-associated health events can be minimized through proper pool chemical labeling, storage, and security. Violations of this critical element were documented by environmental health practitioners during $18.1 \%$ and $9.9 \%$ of routine inspections of pools and hot tubs/spas, respectively. Data reported elsewhere indicate that $87 \%$ (27/31) of reported pool chemical-associated health events resulted from mixing incompatible chemicals, and 69\% (25/36) of pool chemicalassociated health events were caused by poor chemical storage or handling practices (14). Aquatic facility operator training should include pool chemical safety (e.g., how to read pool chemical labels required by the Occupational Safety and Health Administration or the Environmental Protection Agency [MAHC 5.9.2.1.1] to identify incompatible chemical[s] and personal protective equipment needed for safe handling) (MAHC 6.1.2.1.4.6). Safe chemical storage practices include preventing access by unauthorized persons, such as children (MAHC 5.9.1.4); safe chemical handling practices include adding a concentrated pool chemical to water when diluting and not vice versa to prevent splashing of the concentrated chemical, potentially explosive reactions, and release of toxic chlorine gas (MAHC 5.9.2.4.2.1). Exposure to chemical vapors, fumes, or gases should be minimized by ensuring there is no air movement from the chemical storage area into any other interior space of a building intended for occupation (MAHC 4.9.2.6.1). Finally, when the recirculation pump shuts down or fails to generate adequate flow but the automated chemical feeder pumps continue to inject concentrated chlorine and acid into the water, the mixing of concentrated chemicals produces toxic chlorine gas. Restarting the recirculation pump then vents the toxic chlorine gas from the venue plumbing and into the aquatic venue. To prevent this from happening, an electrical interlock should be installed between the automated chemical feeders, the recirculation pumps, and water flow meter/flow switch to shut down automated chemical feeder pumps if the

\footnotetext{
**** Entrapment occurs when a body part (e.g., hair, limb, or buttocks) or something on the swimmer's body (e.g. jewelry or bathing suit) becomes caught in the suction of the recirculation pump or in an underwater structure.
}

recirculation pumps shut down or there is inadequate water flow in the venue plumbing (MAHC 4.7.3.2.1.3).

Violations related to water temperature were documented during $7.5 \%$ of routine inspections of hot tubs/spas. Sitting in high temperature water for a prolonged time essentially mimics fever and poses a risk for hyperthermia in vulnerable persons. For example, young children are still developing the ability to regulate body temperature, and body temperature regulation is especially difficult for infants given their small body mass relative to their body surface area. In addition, data suggest that hot tub/spa use by pregnant women, particularly in the first trimester, might be associated with birth defects $(46,47)$. To minimize the risk for injury related to water temperature, the water temperature should not exceed $104^{\circ} \mathrm{F}\left(40^{\circ} \mathrm{C}\right)$ (MAHC 5.7.4.7.2). Hot tub/spa signage should include text indicating that children aged $<5$ years are prohibited from using hot tubs/spas, pregnant women should not use the hot tub/spa without prior consultation with a health care provider, and the water temperature should not exceed $104^{\circ} \mathrm{F}\left(40^{\circ} \mathrm{C}\right)$ (MAHC 6.4.2.2.3.7). Aquatic facility operators might consider providing accurate thermometers that allow bathers to easily check the hot tub/spa water temperature before entering.

\section{Improving the Collection and Storage of Aquatic Facility Inspection Data}

The process of submitting, reformatting, standardizing, and analyzing 2013 NAFIS data highlighted several areas where the collection and storage of aquatic facility inspection data could be improved. First, data on aquatic facility setting (e.g., apartment/condominium, hotel/motel, and waterpark) were not included in most submitted data sets and pool category (e.g., wading pool and interactive water play venue) for almost all inspected pools was designated as "pool" instead of a specific type of pool. This precluded the characterization of the distribution of immediate closures and violations by aquatic facility setting and limited characterization by pool category. Collecting aquatic facility setting, aquatic venue type, and pool category data enable identification of increased-risk settings, aquatic venue types, and pool categories. Second, data on quantitative results of water quality testing conducted during inspections were not collected or submitted, limiting the interpretation of disinfectant concentration and $\mathrm{pH}$ violation data. Quantitative results of water quality testing are particularly useful when there are different public health implications related to upper and lower limits of mandated water quality parameters. For example, as $\mathrm{pH}$ decreases below 7.2, disinfection effectiveness increases because more of the active form of the halogen (e.g., hypochlorous acid) is formed; however, as $\mathrm{pH}$ decreases below 7.2, bathers are increasingly 
likely to experience skin and eye irritation and the aquatic venue plumbing is more likely to corrode. Alternatively, as $\mathrm{pH}$ increases above 7.8, disinfection effectiveness decreases (because less of the active form of the halogen is available for disinfection), and bathers are again increasingly likely to experience skin and eye irritation. Third, data for which specific inspection items resulted in immediate closures were submitted by only one jurisdiction; these data enable more in-depth characterization of immediate closures and identification of operator training needs. The structure of inspection forms and design of the electronic databases can also be optimized to facilitate analysis. For $10(67 \%)$ of 15 critical illness and injury risk-minimizing MAHC elements (Table 2), at least one NAFIS jurisdiction combined data on multiple inspection items. While this practice expedites data collection and entry and limits data storage needs, it precludes analysis of individual inspection items and leads to an underestimate of the total number of identified violations. Assessing and documenting findings for individual inspection items enables a more comprehensive picture of the operation and maintenance of public aquatic venues. Additionally, structuring databases to efficiently document whether each individual inspection item was in compliance, in violation, or not inspected, could allow for the inclusion of complaint and follow-up inspection data in analyses. Finally, nine (36\%) NAFIS jurisdictions could not participate in this report. Not all NAFIS jurisdictions had electronic data, and among those that did have electronic data, not all could readily access or retrieve their data in time to collaborate on this report. CDC has developed two resources to help optimize the collection and analysis of aquatic facility inspection data: a draft model inspection form (http://www.cdc.gov/mahc/tools-forms.html), which includes approximately $50 \mathrm{MAHC}$ illness and injury risk-minimizing elements that protect public health, and a set of recommendations to improve data collection and database construction (http://www.cdc.gov/healthywater/swimming/ pools/regulation/recommendations-pool-inspection-datacollection.html).

\section{Future Directions}

To optimize the analysis and collection of aquatic facility inspection data, and thus the application of findings, a collaboration of federal, state, and local partners from different disciplines is needed and should include environmental health practitioners with technical knowledge about the operation and maintenance of public aquatic facilities and with inspection experience, epidemiologists skilled in conducting surveillance and data analysis, and information technology specialists with expertise in database construction. This collaboration could provide input on identifying public aquatic facility code elements deemed critical to protecting public health and on the creation of needed resources (e.g., standard inspection forms, training for inspectors, criteria for the construction of databases, and tools to analyze data).

The Council for the Model Aquatic Health Code (CMAHC; http://www.cmahc.org), a national clearinghouse for MAHC change requests that are relayed back to CDC (Appendix B), could facilitate this collaboration and development of resources. This collaboration could, to some degree, standardize data across jurisdictions, including jurisdictions participating in NAFIS. This would enable cross-jurisdictional comparisons, further elucidating the epidemiology of immediate closures and violations of public aquatic facility codes and enabling sharing of environmental health aquatic inspection program lessons learned. Additionally, analysis of NAFIS data can also be used to prioritize revisions or updates to the MAHC itself.

The CMAHC-facilitated collaboration could also serve as a model for the creation of multidisciplinary teams within state or local jurisdictions. These teams could adapt resources as needed for their individual state or local jurisdictions. This team-based approach would increase state and local capacity to use data to inform environmental health aquatic inspection program planning, implementation, and evaluation. Beyond optimizing aquatic facility inspection data for surveillance at the local, state, and multijurisdictional level, these principles can be applied to data collected by other state and local environmental health inspection programs, including those focused on food service establishments and childcare settings.

\section{Limitations}

The findings in this report are subject to at least three limitations. First, these data are not generalizable to U.S. public aquatic facilities and venues nationwide. Second, the number of public aquatic venues inspected and the frequency of routine inspections differs by jurisdiction; thus, some jurisdictions (e.g., Maricopa County in Arizona and Orange County in California) contributed a higher proportion of inspection records to this analysis than other jurisdictions. Finally, the variability in public health codes, and thus in inspection forms, items inspected, and how the same aspect of public aquatic facility operation and maintenance is inspected across jurisdictions limited data analysis (i.e., violations were specific to each jurisdiction and not to an overall standard). 


\section{Conclusion}

With an estimated $15.7 \%$ of U.S. public aquatic venues under surveillance, NAFIS is the first ongoing multijurisdictional surveillance network to use aquatic facility inspection data to monitor the operation and maintenance of public aquatic facilities in the United States. The findings of this report and others $(19,23,24)$, while not directly comparable, are similar: operation and maintenance violations and consequent immediate closures of U.S. public aquatic venues frequently occur. The findings of this report also demonstrate the utility of aquatic facility inspection data; highlight the potential of these data to inform state and local environmental health aquatic inspection program planning, implementation, and evaluation; and underscore the public health function that code enforcement, conducted by environmental health practitioners, plays in preventing illness and injury at public aquatic facilities.

For the aquatics sector and public health to continue to minimize the risk for illness and injury at public aquatic facilities, the following measures are recommended: 1) expanded use of inspection data to inform state and local environmental health aquatic inspection program planning, implementation, and evaluation and 2) broad participation in CMAHC to keep the MAHC current and up to date. Adoption, implementation, and enforcement of the MAHC elements in jurisdictions across the United States could help minimize illness and injury at public aquatic facilities. Collaboration among environmental health practitioners, epidemiologists, and IT specialists nationally and within individual state and local jurisdictions is essential to optimizing aquatic facility inspection data collection and evaluating whether the adoption of MAHC elements minimizes illness and injury at public aquatic facilities.

\section{Acknowledgments}

Rob Blake, Division of Emergency and Environmental Health Services, National Center for Environmental Health, CDC; Matthew Penn, Montrece Ransom, Stacie Close, Julia Charles, Public Health Law Office, Office for State, Tribal, Local, and Territorial Support, CDC; Blanca Caballero, Arizona Department of Health Services; Joyce Tuttle, California Department of Public Health; Katie Moore, Texas Department of State Health Services.

\section{References}

1. Wiltse J. Contested waters: a social history of swimming pools in America. Chapel Hill: University of North Carolina Press; 2007.

2. US Census Bureau. Statistical abstract of the United States: arts, recreation, and travel: participation in selected sports activities. Washington, DC: US Department of Commerce, US Census Bureau; 2012. http://www. census.gov/library/publications/2011/compendia/statab/131ed/artsrecreation-travel.html

3. Data PK. Inc. U.S. swimming pool and hot tub market, Duluth, GA: Data PK Inc.; 2011.
4. CDC. Health benefits of water-based exercise. Atlanta, GA: US Department of Health and Human Services, CDC; 2013. http://www. cdc.gov/healthywater/swimming/health_benefits_water_exercise.html

5. Teutsch SM. Considerations in planning a surveillance system. In: Lee L, Teutsch SM, Thacker SB. Principles and practice of public health surveillance. 2nd ed. New York, NY: Oxford University Press; 2000.

6. CDC. Swimming-associated cryptosporidiosis_Los Angeles County. MMWR Morb Mortal Wkly Rep 1990;39:343-5.

7. Sorvillo FJ, Fujioka K, Nahlen B, Tormey MP, Kebabjian R, Mascola L. Swimming-associated cryptosporidiosis. Am J Public Health 1992;82:742-4. http://dx.doi.org/10.2105/AJPH.82.5.742

8. Hlavsa MC, Roberts VA, Kahler AM, et al. Outbreaks of illness associated with recreational water-United States, 2011-2012. MMWR Morb Mortal Wkly Rep 2015;64:668-72.

9. CDC. Communitywide cryptosporidiosis outbreak-Utah, 2007. MMWR Morb Mortal Wkly Rep 2008;57:989-93.

10. CDC. Respiratory and ocular symptoms among employees of a hotel indoor waterpark resort-Ohio, 2007. MMWR Morb Mortal Wkly Rep 2009;58:81-5.

11. Xu J. Unintentional drowning deaths in the United States, 1999-2010. NCHS Data Brief 2014;149:1-8.

12. CDC. Drowning_-United States, 2005-2009. MMWR Morb Mortal Wkly Rep 2012;61:344-7.

13. Hlavsa MC, Robinson TJ, Collier SA, Beach MJ. Pool chemicalassociated health events in public and residential settings-United States, 2003-2012, and Minnesota, 2013. MMWR Morb Mortal Wkly Rep 2014;63:427-30.

14. CDC. Pool chemical-associated health events in public and residential settings-United States, 1983-2007. MMWR Morb Mortal Wkly Rep 2009;58:489-93.

15. Hlavsa MC, Roberts VA, Anderson AR, et al. Surveillance for waterborne disease outbreaks and other health events associated with recreational waterUnited States, 2007-2008. MMWR Surveill Summ 2011;60:1-32.

16. CDC. Acute illness and injury from swimming pool disinfectants and other chemicals-United States, 2002-2008. MMWR Morb Mortal Wkly Rep 2011;60:1343-7.

17. Anderson AR, Welles WL, Drew J, Orr MF. The distribution and public health consequences of releases of chemicals intended for pool use in 17 states, 2001-2009. J Environ Health 2014;76:10-5.

18. US Census Bureau. Annual estimates of the resident population for incorporated places of 50,000 or more, ranked by July 1,2013 population: April 1, 2010 to July 1, 2013. Washington, DC: US Department of Commerce, US Census Bureau; 2014. https://www.census.gov/popest/ data/cities/totals/2013/index.html

19. CDC. Violations identified from routine swimming pool inspectionsselected states and counties, United States, 2008. MMWR Morb Mortal Wkly Rep 2010;59:582-7.

20. Karch KM. Application of a data processing system to a swimming pool inspection program. Public Health Rep 1965;80:211-9. http://dx.doi. org/10.2307/4592385

21. Vyles T. Growth and evolution of a municipal pool safety and inspection program. J Environ Health 2009;71:40-4.

22. Buss BF, Safranek TJ, Magri JM, Török TJ, Beach MJ, Foley BP. Association between swimming pool operator certification and reduced pool chemistry violations-Nebraska, 2005-2006. J Environ Health 2009;71:36-40.

23. CDC. Surveillance data from swimming pool inspections-selected states and counties, United States, May-September 2002. MMWR Morb Mortal Wkly Rep 2003;52:513-6.

24. CDC. Surveillance data from public spa inspections - United States, MaySeptember 2002. MMWR Morb Mortal Wkly Rep 2004;53:553-5. 
25. National Association of County and City Health Officials. 2013 national profile of local health departments. Washington, DC: National Association of County and City Health Officials; 2014. http:// nacchoprofilestudy.org/wp-content/uploads/2014/02/2013_National_ Profile021014.pdf

26. Johnston K, Kinziger M. Certified operators: Does certification provide significant results in real-world pool and spa chemistry? IJARE 2007;1:18-33.

27. Painter JE, Hlavsa MC, Collier SA, Xiao L, Yoder JS. Cryptosporidiosis surveillance-United States, 2011-2012. MMWR Surveill Summ 2015;64(No. SS-3):1-14.

28. Roy SL, DeLong SM, Stenzel SA, et al.; Emerging Infections Program FoodNet Working Group. Risk factors for sporadic cryptosporidiosis among immunocompetent persons in the United States from 1999 to 2001. J Clin Microbiol 2004;42:2944-51. http://dx.doi.org/10.1128/ JCM.42.7.2944-2951.2004

29. Roy SL, Scallan E, Beach MJ. The rate of acute gastrointestinal illness in developed countries. J Water Health 2006;4(Suppl 2):31-69. http:// dx.doi.org/10.2166/wh.2006.017

30. CDC. Prevalence of parasites in fecal material from chlorinated swimming pools_-United States, 1999. MMWR Morb Mortal Wkly Rep 2001;50:410-2.

31. Gerba CP. Assessment of enteric pathogen shedding by bathers during recreational activity and its impact on water quality. Quant Microbiol 2000;2:55-68. http://dx.doi.org/10.1023/A:1010000230103

32. Amburgey JE, Anderson JB. Disposable swim diaper retention of Cryptosporidium-sized particles on human subjects in a recreational water setting. J Water Health 2011;9:653-8. http://dx.doi.org/10.2166/ wh.2011.063

33. Dufour AP, Evans O, Behymer TD, Cantú R. Water ingestion during swimming activities in a pool: a pilot study. J Water Health 2006;4:425-30.

34. Esterman A, Roder DM, Cameron AS, et al. Determinants of the microbiological characteristics of South Australian swimming pools. Appl Environ Microbiol 1984;47:325-8.

35. Price D, Ahearn DG. Incidence and persistence of Pseudomonas aeruginosa in whirlpools. J Clin Microbiol 1988;26:1650-4.

36. Declerck P. Biofilms: the environmental playground of Legionella pneumophila. Environ Microbiol 2010;12:557-66. http://dx.doi. org/10.1111/j.1462-2920.2009.02025.x
37. Dziuban EJ, Liang JL, Craun GF, et al. Surveillance for waterborne disease and outbreaks associated with recreational water-United States, 2003-2004. MMWR Surveill Summ 2006;55(No. SS-9):1-30.

38. Hlavsa MC, Roberts VA, Kahler AM, et al. Recreational water-associated disease outbreaks_-United States, 2009-2010. MMWR Morb Mortal Wkly Rep 2014;63:6-10.

39. Yoder JS, Hlavsa MC, Craun GF, et al. Surveillance for waterborne disease and outbreaks associated with recreational water use and other aquatic facility-associated health events-United States, 2005-2006. MMWR Surveill Summ 2008;57(No. SS-9):1-29.

40. Murphy JL, Arrowood MJ, Lu X, Hlavsa MC, Beach MJ, Hill VR. Effect of cyanuric acid on the inactivation of Cryptosporidium parvum under hyperchlorination conditions. Environ Sci Technol 2015;49:7348-55. http://dx.doi.org/10.1021/acs.est.5b00962

41. Anderson JR. A study of the influence of cyanuric acid on the bactericidal effectiveness of chlorine. Am J Public Health Nations Health 1965;55:1629-37. http://dx.doi.org/10.2105/AJPH.55.10.1629

42. Fitzgerald GP, DerVartanian ME. Factors influencing the effectiveness of swimming pool bactericides. Appl Microbiol 1967;15:504-9.

43. Shields JM, Arrowood MJ, Hill VR, Beach MJ. The effect of cyanuric acid on the disinfection rate of Cryptosporidium parvum in 20-ppm free chlorine. J Water Health 2009;7:109-14. http://dx.doi.org/10.2166/ wh.2009.008

44. Thompson DC, Rivara FP. Pool fencing for preventing drowning in children. Cochrane Database Syst Rev 2000;(2):CD001047.

45. Pelletier AR, Gilchrist J. Fatalities in swimming pools with lifeguards: USA, 2000-2008. Inj Prev 2011;17:250-3. http://dx.doi.org/10.1136/ ip. 2010.029751

46. Duong HT, Shahrukh Hashmi S, Ramadhani T, Canfield MA, Scheuerle A, Kim Waller D; National Birth Defects Prevention Study. Maternal use of hot tub and major structural birth defects. Birth Defects Res A Clin Mol Teratol 2011;91:836-41. http://dx.doi.org/10.1002/ bdra.20831

47. Moretti ME, Bar-Oz B, Fried S, Koren G. Maternal hyperthermia and the risk for neural tube defects in offspring: systematic review and metaanalysis. Epidemiology 2005;16:216-9. http://dx.doi.org/10.1097/01. ede.0000152903.55579.15 
TABLE 1. Number of public aquatic venues* and routine inspections conducted, by jurisdiction - 16 reporting jurisdictions, Network for Aquatic Facility Inspection Surveillance, United States, 2013

\begin{tabular}{lrr}
\hline Jurisdiction & No. of venues & No. of inspections \\
\hline Arizona & 12,066 & 20,519 \\
Maricopa & 8,853 & 14,874 \\
Mohave & 409 & 419 \\
Pima & 2,488 & 4,733 \\
Yuma & 316 & 493 \\
California & 16,793 & 27,409 \\
Orange & 6,877 & 15,231 \\
San Bernardino & 2,767 & 4,353 \\
San Diego & 7,149 & 7,825 \\
Florida & 16,100 & 32,472 \\
Broward & 4,394 & 9,895 \\
Dade & 3,645 & 6,088 \\
Orange & 2,199 & 4,195 \\
Palm Beach & 3,255 & 6,887 \\
Pinellas & 2,607 & 5,407 \\
New York & 2,022 & 2,439 \\
Suffolk & 802 & 1,250 \\
Sullivan & 557 & 551 \\
Westchester & 663 & 638 \\
Texas & 1,651 & 1,348 \\
Austin & 1,651 & 1,348 \\
Total & 48,632 & 84,187 \\
\hline
\end{tabular}

* Whereas environmental health practitioners conduct inspections of an entire public aquatic facility (the physical place that contains one or more aquatic venues and support infrastructure [e.g., chemical storage space]), a separate inspection report, or record, documents the assessment of each aquatic venue (an artificially constructed structure or modified natural structure where the general public is exposed to water intended for recreational or therapeutic purpose [e.g., pools and hot tubs/spas]) within the public aquatic facility. 
TABLE 2. Rationale for 15 critical illness and injury risk-minimizing Model Aquatic Health Code (MAHC) elements, by illness or injury and number of participating jurisdictions* -16 reporting jurisdictions, Network for Aquatic Facility Inspection Surveillance, United States, 2013

\begin{tabular}{|c|c|c|c|c|}
\hline Critical element & Rationale & $\begin{array}{c}\text { No. of } \\
\text { jurisdictions } \\
\text { contributing } \\
\text { inspection } \\
\text { data }\end{array}$ & $\begin{array}{c}\text { No. of } \\
\text { jurisdictions } \\
\text { not } \\
\text { collecting } \\
\text { inspection } \\
\text { data } \\
\text { or unable to } \\
\text { share these } \\
\text { data }\end{array}$ & $\begin{array}{c}\text { No. of } \\
\text { jurisdictions } \\
\text { combining } \\
\text { inspection data } \\
\text { on multiple } \\
\text { inspections } \\
\text { items, } \\
\text { precluding } \\
\text { analysis }\end{array}$ \\
\hline \multicolumn{5}{|c|}{ Aquatic facility-associated illness prevention elements } \\
\hline $\begin{array}{l}\text { Proper free available chlorine or } \\
\text { bromine concentration }\end{array}$ & $\begin{array}{l}\text { Prevent transmission of infectious pathogens and reduce creation of } \\
\text { disinfection by-products }\end{array}$ & 14 & 2 & 0 \\
\hline Proper $\mathrm{pH}$ & $\begin{array}{l}\text { Balance maximizing inactivation of infectious pathogens by free available } \\
\text { chlorine or bromine while minimizing skin and eye irritation and } \\
\text { corrosion of aquatic venue plumbing }\end{array}$ & 11 & 5 & 0 \\
\hline $\begin{array}{l}\text { Recirculation pump approved, in } \\
\text { good repair, or operating }\end{array}$ & $\begin{array}{l}\text { Transport water from aquatic venue via the main drain or other suction } \\
\text { outlets, into venue plumbing, and through filter; continue to circulate } \\
\text { water through plumbing so that halogen (chlorine or bromine) and } \\
\text { pH-adjusting chemical can be added, diluted, and then mixed; and return } \\
\text { treated water into aquatic venue via inlets, water jets, or spray features } \\
\text { from venue plumbing }\end{array}$ & 1 & 7 & 8 \\
\hline $\begin{array}{l}\text { Filter approved, in good repair, or } \\
\text { operable }\end{array}$ & $\begin{array}{l}\text { Remove particles from water, including those that bind with and deplete } \\
\text { free available chlorine or bromine }\end{array}$ & 1 & 9 & 6 \\
\hline $\begin{array}{l}\text { Automated chemical feeder in } \\
\text { good repair or operable }\end{array}$ & $\begin{array}{l}\text { Add halogen (chlorine or bromine, which when diluted become free } \\
\text { available chlorine or bromine, respectively) and pH-adjusting chemical to } \\
\text { water in plumbing to optimize inactivation of infectious pathogens }\end{array}$ & 10 & 4 & 2 \\
\hline \multicolumn{5}{|c|}{ Drowning and entrapment ${ }^{\dagger}$ prevention elements } \\
\hline $\begin{array}{l}\text { Enclosure: Fencing, walls, gates, and } \\
\text { doors in good repair or self-closing } \\
\text { and self-latching gates and doors }\end{array}$ & $\begin{array}{l}\text { Prevent drowning by preventing unsupervised entry by young children } \\
\text { and unauthorized entry outside operational hours }\end{array}$ & 14 & 2 & 0 \\
\hline Water clear or main drain visible & $\begin{array}{l}\text { Prevent drowning and other injury by ensuring visibility of persons, } \\
\text { including in deepest water in aquatic venue }\end{array}$ & 9 & 2 & 5 \\
\hline $\begin{array}{l}\text { Main drain covers compliant with } \\
\text { Virginia Graeme Baker Pool and Spa } \\
\text { Safety Act (15 U.S.C. } § \$ 8001 \text { et } \\
\text { seq.) or with ASME/ANSI A112.19.8 } \\
\text { or covers/grates of suction outlets } \\
\text { secured in place or in good repair }\end{array}$ & Prevent entrapment & 13 & 3 & 0 \\
\hline $\begin{array}{l}\text { Qualified or adequately staffed } \\
\text { lifeguards }\end{array}$ & Prevent drowning by recognizing and rescuing distressed bathers & 2 & 5 & 9 \\
\hline $\begin{array}{l}\text { Appropriate safety equipment (e.g., } \\
\text { hook or ring) or in good repair or } \\
\text { first aid kit present }\end{array}$ & $\begin{array}{l}\text { Prevent drowning by providing equipment to rescue distressed bathers, } \\
\text { with or without lifeguard on duty }\end{array}$ & 10 & 3 & 3 \\
\hline \multicolumn{5}{|c|}{ Prevention elements for pool chemical-associated health events and other nondrowning and nonentrapment injuries } \\
\hline $\begin{array}{l}\text { Chemicals labeled, stored safely, or } \\
\text { secured }\end{array}$ & Prevent pool chemical-associated health events & 5 & 5 & 6 \\
\hline Hot tub/spa temperature $\leq 104^{\circ} \mathrm{F}\left(40^{\circ} \mathrm{C}\right)$ & Prevent hyperthermia & 11 & 2 & 3 \\
\hline $\begin{array}{l}\text { Protected overhead electrical } \\
\text { wires or GFCI-protected } \\
\text { electrical outlets }\end{array}$ & $\begin{array}{l}\text { Prevent electrocution, electric shock, burns, and falls caused by contact } \\
\text { with electrical energy }\end{array}$ & 9 & 6 & 1 \\
\hline \multicolumn{5}{|l|}{ General health and safety elements } \\
\hline $\begin{array}{l}\text { Qualified operator or responsible } \\
\text { supervisor on site }\end{array}$ & $\begin{array}{l}\text { Prevent aquatic facility-associated illness and injury by ensuring optimal } \\
\text { operation and maintenance }\end{array}$ & 6 & 8 & 2 \\
\hline $\begin{array}{l}\text { Substantial alterations or } \\
\text { equipment replacement approved }\end{array}$ & $\begin{array}{l}\text { Prevent aquatic facility-associated illness and injury by ensuring new } \\
\text { design, construction, and equipment meet code }\end{array}$ & 10 & 6 & 0 \\
\hline
\end{tabular}

Abbreviations: ASME = American Society of Mechanical Engineers; ANSI = American National Standards Institute; GFCl = ground fault circuit interrupter.

* Inspection forms, items inspected, and even how the same aspect of public aquatic facility operation and maintenance is inspected vary across jurisdictions. Thus, the numbers of jurisdictions contributing data to the examination of each MAHC element varies.

† Entrapment occurs when a body part (e.g., hair, limb, or buttocks) or something on the swimmer's body (e.g., jewelry or bathing suit) becomes caught in the suction of the recirculation pump or in an underwater structure. 
TABLE 3. Percentage of routine inspections $\left(N=84,187^{*}\right)$ of public aquatic venues with identified jurisdiction-specific violations, by aquatic venue type and corresponding 15 critical illness and injury risk-minimizing Model Aquatic Health Code elements - 16 reporting jurisdictions, Network for Aquatic Facility Inspection Surveillance, United States, 2013

\begin{tabular}{|c|c|c|c|c|}
\hline \multirow[b]{3}{*}{ Characteristic } & \multicolumn{4}{|c|}{ Aquatic venue type } \\
\hline & \multicolumn{4}{|c|}{$\begin{array}{l}\% \text { (No. of inspections identifying jurisdiction-specific violation of inspection item [s] / } \\
\text { No. of inspections assessing inspection item }[\mathrm{s}] \text { ) }\end{array}$} \\
\hline & Pool $(n=55,913)$ & Hot tub/spa $(n=20,449)$ & Unknown $(n=7,825)$ & Total $(n=84,187)$ \\
\hline Serious violation(s) leading to closure & $11.8(5,139 / 43,636)$ & $15.1(2,217 / 14,637)$ & $9.7(762 / 7,825)$ & $12.3(8,118 / 66,098)$ \\
\hline \multicolumn{5}{|c|}{ Aquatic facility-associated illness prevention elements } \\
\hline $\begin{array}{l}\text { Proper free available chlorine or bromine } \\
\text { concentration }\end{array}$ & $9.2(3,927 / 42,891)$ & $19.2(2,663 / 13,864)$ & $13.7(1,072 / 7,825)$ & $11.9(7,662 / 64,580)$ \\
\hline Proper $\mathrm{pH}$ & $12.4(5,017 / 40,533)$ & $27.5(3,789 / 13,783)$ & $5.5(430 / 7,825)$ & $14.9(9,236 / 62,141)$ \\
\hline $\begin{array}{l}\text { Recirculation pump approved, in good } \\
\text { repair, or operating }\end{array}$ & $1.5(148 / 9,656)$ & $1.3(72 / 5,575)$ & $-^{\dagger}$ & $1.4(220 / 15,231)$ \\
\hline Filter approved, in good repair, or operable & $2.2(216 / 9,656)$ & $1.3(71 / 5,575)$ & - & $1.9(287 / 15,231)$ \\
\hline $\begin{array}{l}\text { Automated chemical feeder in good repair } \\
\text { or operable }\end{array}$ & $6.2(2,378 / 38,401)$ & $4.5(531 / 11,741)$ & $1.6(122 / 7,825)$ & $5.2(3,031 / 57,967)$ \\
\hline \multicolumn{5}{|c|}{ Drowning and entrapment prevention elements } \\
\hline $\begin{array}{l}\text { Enclosure: Fencing, walls, gates, and doors } \\
\text { in good repair or self-closing and } \\
\text { self-latching gates and doors }\end{array}$ & $5.7(2,449 / 42,891)$ & $2.8(389 / 13,864)$ & $5.9(465 / 7,825)$ & $5.1(3,303 / 64,580)$ \\
\hline Water clear or main drain visible & $1.4(226 / 16,501)$ & $2.1(162 / 7,779)$ & $0.4(32 / 7,825)$ & $1.3(420 / 32,105)$ \\
\hline $\begin{array}{l}\text { Main drain covers compliant with Virginia } \\
\text { Graeme Baker Pool and Spa Safety Act (15 } \\
\text { U.S.C. } \S \S 8001 \text { et seq.) or with ASME/ANSI } \\
\text { A112.19.8 or covers/grates of suction } \\
\text { outlets secured in place or in good repair }\end{array}$ & $1.3(537 / 42,520)$ & $1.0(142 / 13,673)$ & $0.8(60 / 7,825)$ & $1.2(739 / 64,018)$ \\
\hline Qualified or adequately staffed lifeguards & $0(0 / 9,656)$ & $0(0 / 5,575)$ & $0.1(10 / 7,825)$ & $0(10 / 23,056)$ \\
\hline $\begin{array}{l}\text { Appropriate safety equipment (e.g., hook or } \\
\text { ring) or in good repair or first aid kit } \\
\text { present }\end{array}$ & $16.6(6,689 / 40,231)$ & $1.3(175 / 13,592)$ & $12.5(981 / 7,825)$ & $12.7(7,845 / 61,648)$ \\
\hline \multicolumn{5}{|c|}{ Prevention elements of pool chemical-associated health events and other nondrowning and nonentrapment injuries } \\
\hline Chemicals labeled, stored safely, or secured & $18.1(427 / 2,358)$ & $9.9(8 / 81)$ & $0.5(36 / 7,825)$ & $4.6(471 / 10,264)$ \\
\hline Hot tub/spa temperature $\leq 104^{\circ} \mathrm{F}\left(40^{\circ} \mathrm{C}\right)$ & NA & $7.5(1,037 / 13,783)$ & NA & $7.5(1,037 / 13,783)$ \\
\hline $\begin{array}{l}\text { Protected overhead electrical wires or } \\
\text { GFCl- electrical outlets }\end{array}$ & $0.3(129 / 38,401)$ & $0.3(33 / 11,741)$ & - & $0.3(162 / 50,142)$ \\
\hline \multicolumn{5}{|l|}{ General health and safety elements } \\
\hline $\begin{array}{l}\text { Qualified operator or responsible supervisor } \\
\text { on site }\end{array}$ & $1.8(222 / 12,014)$ & $1.0(56 / 5,656)$ & $0.2(13 / 7,825)$ & $1.1(291 / 25,495)$ \\
\hline $\begin{array}{l}\text { Substantial alterations or equipment } \\
\text { replacement approved }\end{array}$ & $0.4(173 / 41,217)$ & $0.3(41 / 13,278)$ & - & $0.4(214 / 54,495)$ \\
\hline
\end{tabular}

Abbreviations: ASME = American Society of Mechanical Engineers; ANSI = American National Standards Institute; GFCl = ground fault circuit interrupter; NA = not applicable.

* The denominators vary because of differences in the number of jurisdictions contributing inspection data to examine a given critical element.

${ }^{\dagger}$ No data available. 
TABLE 4. Percentage of routine inspections $\left(N=55,913^{*}\right)$ of public pools with identified jurisdiction-specific violations, by pool type and corresponding 15 critical illness and injury risk-minimizing Model Aquatic Health Code elements - 16 reporting jurisdictions, Network for Aquatic Facility Inspection Surveillance, United States, 2013

\begin{tabular}{|c|c|c|c|c|c|}
\hline \multirow[b]{3}{*}{ Characteristic } & \multicolumn{5}{|c|}{ Pool category } \\
\hline & \multicolumn{5}{|c|}{$\begin{array}{l}\% \text { (No. of inspections identifying jurisdiction-specific violation of inspection item [s]/ } \\
\text { No. of inspections assessing inspection item }[s] \text { ) }\end{array}$} \\
\hline & $\begin{array}{c}\text { Pool } \\
(n=53,537)\end{array}$ & $\begin{array}{l}\text { Wading pool } \\
\qquad(\mathrm{n}=1,606)\end{array}$ & $\begin{array}{l}\text { Interactive water play } \\
\text { venue }(n=69)\end{array}$ & $\begin{array}{l}\text { Other } \\
(n=701)\end{array}$ & $\begin{array}{c}\text { Overall } \\
(n=55,913)\end{array}$ \\
\hline $\begin{array}{l}\text { Serious violation(s) leading } \\
\text { to closure }\end{array}$ & $11.6(4,873 / 42,161)$ & $21.6(205 / 948)$ & $12.1(8 / 66)$ & $11.5(53 / 461)$ & $11.8(5,139 / 43,636)$ \\
\hline \multicolumn{6}{|c|}{ Aquatic facility-associated illness prevention elements } \\
\hline $\begin{array}{l}\text { Proper free available chlorine or } \\
\text { bromine concentration }\end{array}$ & $8.7(3,549 / 40,585)$ & $19.2(303 / 1,581)$ & $10.1(7 / 69)$ & $10.4(68 / 656)$ & $9.2(3,927 / 42,891)$ \\
\hline Proper $\mathrm{pH}$ & $11.8(4,506 / 38,247)$ & $26.0(411 / 1,581)$ & $6.1(4 / 66)$ & $15.0(96 / 639)$ & $12.4(5,017 / 40,533)$ \\
\hline $\begin{array}{l}\text { Recirculation pump approved, in } \\
\text { good repair, or operating }\end{array}$ & $1.6(139 / 8,775)$ & $0.8(5 / 658)$ & -9 & $1.8(4 / 223)$ & $1.5(148 / 9,656)$ \\
\hline $\begin{array}{l}\text { Filter approved, in good repair, } \\
\text { or operable }\end{array}$ & $2.3(203 / 8,775)$ & $1.7(11 / 658)$ & - & $0.9(2 / 223)$ & $2.2(216 / 9,656)$ \\
\hline $\begin{array}{l}\text { Automated chemical feeder in } \\
\text { good repair or operable }\end{array}$ & $6.3(2,260 / 36,137)$ & $6.1(94 / 1,539)$ & $5.8(4 / 69)$ & $3.0(20 / 656)$ & $6.2(2,378 / 38,401)$ \\
\hline \multicolumn{6}{|c|}{ Drowning and entrapment prevention elements } \\
\hline $\begin{array}{l}\text { Enclosure: fencing, walls, gates, } \\
\text { and doors in good repair or } \\
\text { self-closing and self-latching } \\
\text { gates and doors }\end{array}$ & $5.9(2,413 / 40,585)$ & $1.3(21 / 1,581)$ & $1.4(1 / 69)$ & $2.1(14 / 656)$ & $5.7(2,449 / 42,891)$ \\
\hline Water clear or main drain visible & $1.4(222 / 15,561)$ & $0.4(3 / 700)$ & NA & $0.4(1 / 240)$ & $1.4(226 / 16,501)$ \\
\hline $\begin{array}{l}\text { Main drain covers compliant with } \\
\text { Virginia Graeme Baker Pool and } \\
\text { Spa Safety Act (15 U.S.C. §§ } \\
8001 \text { et seq.) or with ASME/ANSI } \\
\text { A112.19.8 or covers/grates of } \\
\text { suction outlets secured in place } \\
\text { or in good repair }\end{array}$ & $1.3(517 / 40,283)$ & $1.1(17 / 1,581)$ & NA & $0.5(3 / 656)$ & $1.3(537 / 42,520)$ \\
\hline $\begin{array}{l}\text { Qualified or adequately staffed } \\
\text { lifeguards }\end{array}$ & $0(0 / 8,775)$ & $0(0 / 658)$ & NA & $0(0 / 223)$ & $0(0 / 9,656)$ \\
\hline $\begin{array}{l}\text { Appropriate safety equipment } \\
\text { (e.g., hook or ring) or in good } \\
\text { repair or first aid kit present }\end{array}$ & $17.5(6,638 / 37,945)$ & $1.2(19 / 1,581)$ & $0(0 / 66)$ & $5.0(32 / 639)$ & $16.6(6,689 / 40,231)$ \\
\hline \multicolumn{6}{|c|}{ Prevention elements of pool chemical-associated health events and other nondrowning and nonentrapment injuries } \\
\hline $\begin{array}{l}\text { Chemicals labeled, stored safely, } \\
\text { or secured }\end{array}$ & $18.2(425 / 2,338)$ & - & $0(0 / 3)$ & $11.8(2 / 17)$ & $18.1(427 / 2,358)$ \\
\hline $\begin{array}{l}\text { Protected overhead electrical } \\
\text { wires or GFCl-electrical outlets }\end{array}$ & $0.3(125 / 36,137)$ & $0.2(3 / 1,539)$ & $0(0 / 69)$ & $0.2(1 / 656)$ & $0.3(129 / 38,401)$ \\
\hline \multicolumn{6}{|l|}{ General health and safety elements } \\
\hline $\begin{array}{l}\text { Qualified operator or } \\
\text { responsible supervisor on site }\end{array}$ & $1.9(211 / 11,113)$ & $1.7(11 / 658)$ & $0(0 / 3)$ & $0(0 / 240)$ & $1.8(222 / 12,014)$ \\
\hline $\begin{array}{l}\text { Substantial alterations or } \\
\text { equipment replacement } \\
\text { approved }\end{array}$ & $0.4(169 / 38,953)$ & $0.1(1 / 1,539)$ & $0(0 / 69)$ & $0.5(3 / 656)$ & $0.4(173 / 41,217)$ \\
\hline
\end{tabular}

Abbreviations: $\mathrm{ASME}$ = American Society of Mechanical Engineers; $\mathrm{ANSI}=$ American National Standards Institute; $\mathrm{GFCl}=$ ground fault circuit interrupter; $\mathrm{NA}=$ not applicable.

* The denominators vary because of differences in the number of jurisdictions contributing inspection data to examine a given critical element.

† For terminology to be aligned with CDC's Model Aquatic Health Code, the term "wading pool" has replaced the term "kiddie/wading pool," which has historically been used by CDC in MMWR reports and surveillance summaries.

$\S$ Other includes special purpose pools, water attractions, water activity, water slides, and lazy rivers. Previous CDC MMWR reports on pool inspection data included "therapy pools." "Therapy pool" is not included in this table because no inspection data on therapy pools were reported.

" No data available. 
TABLE 5. Summary of findings of previous reports* of analysis of data collected during inspections of public aquatic facilities ${ }^{\dagger}$ in multiple jurisdictions - selected jurisdictions, United States, 2002 and 2008

\begin{tabular}{|c|c|c|c|}
\hline Characteristic & Public hot tub/spa inspections ${ }^{\S}$ & Public pool inspections ${ }^{\pi}$ & Public pool inspections** \\
\hline $\begin{array}{l}\text { No. of participating state or local } \\
\text { jurisdictions }\end{array}$ & 6 & 6 & 15 \\
\hline $\begin{array}{l}\text { Methodology for selecting jurisdictions } \\
\text { with electronic inspection data }\end{array}$ & Convenience sample & Convenience sample & $\begin{array}{c}\text { Convenience sample of jurisdictions with } \\
\geq 1,000 \text { inspection records for } 2008\end{array}$ \\
\hline Type of violation documented & $\begin{array}{l}\text { No. of violations documented (\% of } \\
\text { inspections identifying violation of } \\
\text { inspection item[s]) }\end{array}$ & $\begin{array}{l}\text { No. of violations documented (\% of } \\
\text { inspections identifying violation of } \\
\text { inspection item[s]) }\end{array}$ & $\begin{array}{l}\text { No. inspections assessing inspection } \\
\text { item(s) (\% inspections identifying } \\
\text { violation of inspection item[s]) }\end{array}$ \\
\hline Serious violation(s) leading to closure & $500(11.0)$ & $-^{\dagger \dagger}(8.3)$ & $111,487(12.1)$ \\
\hline Disinfectant concentration & $889(17.1)$ & $2,460(11.1)$ & $120,975(10.7)$ \\
\hline $\mathrm{pH}$ & $757(14.6)$ & $1,718(7.8)$ & $113,597(8.9)$ \\
\hline Other water chemistry & $903(17.3)^{\S \S}$ & $3,769(17.0)^{\text {กิ }}$ & $98,907(12.5)^{* * *}$ \\
\hline Filtration/recirculation system & $1,419(27.3)^{\dagger+\dagger}$ & $6,604(29.9)^{\S \S \S}$ & 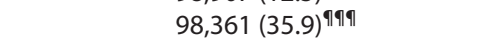 \\
\hline Test kit & $105(2.0)$ & $740(3.4)$ & $90,088(3.3)$ \\
\hline Operator training & $162(23.3)$ & $604(25.1)$ & $8,439(18.3)$ \\
\hline Aquatic venue log & $654(12.7)$ & $3,522(16.5)$ & $115,874(10.9)$ \\
\hline Aquatic venue license & - & $26(3.6)$ & $28,007(2.7)$ \\
\hline
\end{tabular}

* The findings cannot be compared directly across reports because the timeframes, inspection items, or jurisdictions vary across reports.

+ Whereas environmental health practitioners conduct inspections of an entire public aquatic facility (the physical place that contains one or more aquatic venues and support infrastructure [e.g., chemical storage space]), a separate inspection report, or record, documents the assessment of each aquatic venue (an artificially constructed structure or modified natural structure where the general public is exposed to water intended for recreational or therapeutic purpose [e.g., pools and hot tubs/spas]) within the public aquatic facility.

$\S$ Source: CDC. Surveillance data from public spa inspections-United States, May-September 2002. MMWR Morb Mortal Wkly Rep 2004;53:553-5.

ๆ Source: CDC. Surveillance data from swimming pool inspections-selected states and counties, United States, May-September 2002. MMWR Morb Mortal Wkly Rep 2003;52:513-6.

** Source: CDC. Violations identified from routine swimming pool inspections_selected states and counties, United States, 2008. MMWR Morb Mortal Wkly Rep 2010;59:582-7.

t+ Count not available.

$\S \S$ Aggregate variable. A positive could include one or more violations in any area (e.g., algae, bacterial quality, calcium hardness, cyanurate levels, disinfectant/pH chemical feeders, total alkalinity, and turbidity).

१ต Aggregate variable. A positive could include one or more violations in any area (e.g., algae, bacterial quality, calcium hardness, cyanurate levels, disinfectant/pH chemical feeders, and total alkalinity).

*** Aggregated, dichotomous variable indicating whether at least one of the following inspection items was found to be in violation: algae, bacterial quality, calcium hardness, cyanurate levels, disinfectant/pH chemical feeders, oxidation reduction potential, saturation index, total alkalinity, and total dissolved solids.

${ }^{\dagger+\dagger}$ Aggregate variable. A positive could include one or more violations in any area (e.g., backwash, cross connections, filter, flow meter, pressure gauges, recirculation system, and turnover).

$\S \S$ Aggregate variable. A positive could include one or more violations in any area (e.g., backwash, cross connections, filter, flow meter, pressure gauges, recirculation system, turnover, and turbidity).

กศศ Aggregated, dichotomous variable indicating whether at least one of the following inspection items was found to be in violation: cross connections, filter, flow meter, gauges, pipe labeling, skimmer/gutter, turbidity, turnover, water level, and weirs. 


\section{APPENDIX A}

\section{Glossary of Terms Used in This Report}

"Aquatic facility" means a physical place that contains one or more aquatic venues (e.g., a pool or hot tub/spa) and support infrastructure (e.g., chemical storage area).

"Aquatic venue" means an artificially constructed structure or modified natural structure where the general public is exposed to water intended for recreational or therapeutic purpose. Such structures do not necessarily contain standing water, so water exposure might occur via contact, ingestion, or inhalation. Examples include wave pools, lazy rivers, surf pools, hot tubs/ spas, therapy pools, waterslide landing pools, and interactive water play venues.

"Free available chlorine" means the portion of the total chlorine that has not combined with other compounds (e.g., combined with nitrogenous compounds to form dichloramine or trichloramine) and is present as hypochlorous acid ( $\mathrm{HOCl})$ or hypochlorite ion $\left(\mathrm{OCl}^{-}\right)$. The $\mathrm{pH}$ of the water determines the relative amounts of hypochlorous acid and hypochlorite ion. $\mathrm{HOCl}$ is a very effective bactericide and is the active bactericide in the water. $\mathrm{OCl}^{-}$is also a bactericide but acts more slowly than $\mathrm{HOCl}$. As $\mathrm{pH}$ decreases, more $\mathrm{HOCl}$ is formed; however, as $\mathrm{pH}$ increases more $\mathrm{OCl}$ - is formed. Thus, chlorine is a more effective bactericide at $\mathrm{pH} \leq 7.8$ than at $\mathrm{pH}>7.8$. Free available chlorine concentration must be maintained for adequate disinfection.

"Hot tub/spa" means a structure intended for either warm or cold water where prolonged exposure is not intended. Hot tub/spa structures are intended to be used for bathing or other recreational uses and are not usually drained and refilled after each use. Hot tubs/spas might be used for hydrotherapy and might have air induction bubbles and a recirculation system.

"Interactive water play venue" means any indoor or outdoor installation that includes sprayed, jetted, or other water sources contacting bathers and not incorporating standing or captured water as part of the bather activity area. These aquatic venues are also known as splash pads, spray pads, wet decks, and water playgrounds.

"Pool" means a subset of aquatic venues designed to have standing water for total or partial bather immersion. This does not include hot tubs/spas.

"Wading pool" means any pool used exclusively for wading and intended for use by young children where the depth does not exceed 2 feet $(0.6 \mathrm{~m})$. 


\section{APPENDIX B}

\section{CDC's Model Aquatic Health Code}

\section{Need for the Model Aquatic Health Code}

Preventing aquatic facility-associated illness and injury calls for a strategy that requires at least three key components (known as the three E's) of environmental health practice: education, engineering, and enforcement. In the United States, individual state and local public health jurisdictions write, enact, implement, and enforce their own unique public health codes covering the design, construction, operation, maintenance, and management of public aquatic facilities; residential aquatic facilities are usually covered under building codes. CDC's Model Aquatic Health Code (MAHC; http://www.cdc.gov/ mahc/) is national guidance that can be voluntarily adopted by state and local jurisdictions to minimize the risk of illness and injury at public aquatic venues. The MAHC includes recommendations for education- and engineering-based strategies, and when voluntarily adopted by state and local jurisdictions it also becomes an enforcement-based strategy.

\section{Education}

Aquatic facility operators and staff, public health officials (e.g., environmental health practitioners, who inspect public aquatic facilities, epidemiologists, and health communication specialists), bathers, and parents of young bathers all need to be engaged to minimize the risk for aquatic facility-associated illness and injury. Ensuring that each stakeholder knows the steps to take to help prevent aquatic facility-associated outbreaks, drowning, and pool chemical-associated health events is necessary to promoting healthy and safe swimming. To properly operate and maintain public aquatic facilities, operators need training that includes essential topics such as water disinfection and chemistry, mechanical systems (including air handling systems), and other illness and injury risk-minimizing strategies. Studies have found that jurisdictions or public aquatic facilities requiring operator training have fewer violations and better disinfectant concentrations and $\mathrm{pH}$ than those jurisdictions or public aquatic facilities without such a requirement $(1,2)$. Environmental health practitioners need to maintain current knowledge about the design, construction, operation, and maintenance of public aquatic facilities and the prevention of aquatic facility-associated illness and injury. Environmental health practitioners sometimes write and enact public aquatic facility codes and always implement and enforce them. Environmental health practitioners enforce design and construction standards through plan review and preoperational inspections, conducted after new construction or substantial alteration, and enforce operation and maintenance standards through routine, complaint, and follow-up inspections.

The aquatics sector and public health should collaborate to disseminate healthy and safe swimming messages to bathers and parents of young bathers. Parents of young bathers are a particularly important group to engage given that young bathers (i.e., those aged $<5$ years) are a primary source of microbiologic contamination of water in aquatic venues. The aquatics sector and public health should promote healthy and safe swimming year-round, and especially during Healthy and Safe Swimming Week (the week before Memorial Day) and the summer swim season (Memorial Day through Labor Day). This can be done via websites (e.g., http://www.cdc.gov/healthywater/swimming) and increasingly via social media (http://www.cdc.gov/healthywater/ swimming/resources/socialmedia-library.html). Healthy swimming education campaigns conducted before aquatic facility-associated outbreaks of infectious etiology occur might help prevent them (3). The public needs to understand the potential risks associated with the use of public aquatic facilities and how they can help keep themselves and others healthy (4). Healthy swimming messages for all bathers include: do not swim while ill with diarrhea, do not swallow water while swimming, and shower before entering the water. To promote adoption of healthy swimming behaviors by the public, healthy swimming education campaigns need to dispel commonly held but mistaken beliefs (e.g., that pool water is sterile and that chlorine instantly inactivates all infectious pathogens), which likely lead to swimming with diarrheal illness and thus potential introduction and transmission of infectious pathogens (5). Drowning prevention messages for the public include making sure everyone knows how to swim, fencing off pools to keep children away, using life jackets appropriately, providing continuous and close supervision of young swimmers, and knowing cardiopulmonary resuscitation. The principal pool chemical safety messages for those storing and handling pool chemicals include: secure pool chemicals away from children and read the Occupational Safety and Health Administration- or Environmental Protection Agency-required pool chemical labels, which identify incompatible chemical(s) and personal protective equipment needed for safe handling (http:// www.cdc.gov/healthywater/swimming/pools/preventing-poolchemical-injuries.html).

\section{Engineering}

Filtration and halogen (e.g., chlorine or bromine) disinfection post filtration prevent transmission of most infectious pathogens in the water of aquatic venues. Typically, an aquatic venue's recirculation pump transports the water out of the venue basin via the main drain or other suction outlets, into the venue plumbing, and through the filter to remove particles that can bind with and deplete halogens. The water continues to circulate through the 
venue plumbing so that the halogen and $\mathrm{pH}$-adjusting chemical (used to optimize inactivation of infectious pathogens and swimmer comfort simultaneously) can be added, diluted, and then mixed. Finally the treated water returns to the aquatic venue via inlets, water jets, or spray features. At CDC-recommended concentrations, ${ }^{*}$ halogens inactivate most infectious pathogens within minutes but the extremely halogen-tolerant parasite, Cryptosporidium, can survive for days $(6,7)$. This means the transmission of halogen-susceptible infectious pathogens (e.g., E. coli O157:H7 or Shigella spp.) can be prevented but the transmission of Cryptosporidium cannot at CDC-recommended halogen concentrations. The emergence of Cryptosporidium as the leading etiology of aquatic facility-associated outbreaks has led to engineering innovations to inactivate (e.g., ultraviolet light or ozone treatment) or remove (e.g., flocculants and improved filter media) the parasite.

Public aquatic facilities can be designed to minimize the risk of drowning. Fencing, walls, and self-closing and selflatching gates and doors can prevent unsupervised entry by young children and unauthorized entry outside operational hours. Aquatic venue design can improve bather visibility for lifeguards and bathers. Additionally, the advent of interactive water play venues, which do not have standing water above ground because the water drains into an underground tank, also minimizes the risk for drowning.

Finally, toxic chlorine gas can be generated if chlorine and acid are not diluted sufficiently before mixing. This can occur when they are mixed by aquatics staff or in aquatic venue plumbing when there is inadequate water flow. When the recirculation pump shuts down or fails to generate adequate flow but the automated chemical feeder pumps continue to inject concentrated chemicals into the water, the mixing of these two concentrated chemicals produces toxic chlorine gas. Restarting the recirculation pump then vents the toxic chlorine gas from the venue plumbing and into the aquatic venue. To prevent this from happening, an electrical interlock should be installed between the automated chemical feeders, the recirculation pumps, and water flow meter/flow switches to shut down automated chemical feeder pumps if the recirculation pumps shut down or there is inadequate water flow in the venue plumbing.

\section{Enforcement}

There are no minimum national standards for training aquatic facility operators or comprehensive standards for the engineering of public aquatic facilities to prevent illness

\footnotetext{
* At the CDC-recommended $\mathrm{pH}$ of 7.2-7.8, CDC recommends maintaining free available chlorine at a minimum of $3 \mathrm{ppm}$ in hot tubs/spas and $1 \mathrm{ppm}$ in other aquatic venues or free available bromine at a minimum of $4 \mathrm{ppm}$ in hot tubs/spas and $3 \mathrm{ppm}$ in other aquatic venues.
}

and injury. No U.S. federal agency regulates the design, construction, operation, and maintenance of public aquatic facilities, although some federal regulations pertain to specific aspects of public aquatic facilities. For example, the Virginia Graeme Baker Pool and Spa Safety Act (15 U.S.C. $\$ \$ 8001$ et seq.) aims to prevent main drain-associated entrapment. ${ }^{\dagger}$ Individual state and local jurisdictions write, enact, implement, and enforce their own unique public aquatic facility codes, leading to variability in state and local codes. This variability is further compounded by how resource intensive it is to update these codes (e.g., staffing, time, and expertise needed), difficult it is to set standards in the absence of scientific data, and the variability in timeframes within which individual state and local jurisdictions update their codes. Consequently, emerging public health threats (e.g., Cryptosporidium) and aquatics sector innovations, which might pose novel risks for aquatic facility-associated illness or injury or conversely minimize long-established risk, might not be addressed on a timely basis across the United States.

\section{Development of the MAHC}

In response to the increasing incidence of aquatic facilityassociated outbreaks, particularly those caused by Cryptosporidium, the Council for State and Territorial Epidemiologists, in 2004, called for CDC to hold a national workshop to develop prevention recommendations (http://c.ymcdn.com/sites/www.cste.org/ resource/resmgr/PS/04-ID-03-FINAL.pdf). In 2005, CDC held the Recreational Water Illness Prevention Workshop for local, state, and federal public health officials and aquatics sector representatives. Workshop attendees identified two barriers to preventing the outbreaks: the variability in public aquatic facility codes across the United States and the resource-intensive effort required to keep each of these codes updated. The workshop attendees' primary recommendation was for CDC to lead a national consortium of public health officials and aquatics sector representatives to develop an open-access model code, based on the latest scientific data and best practices when scientific data were not available. To maximize the model code's utility, attendees recommended that the scope be expanded to be an all-inclusive, all-hazards facility-based code that not only aimed to prevent transmission of infectious pathogens but also injury (e.g., drowning and pool chemical-associated health events), as well as poor indoor air quality and other potential adverse exposures at public aquatic facilities. Such a code would cover all of the pertinent aspects of an aquatic facility's life, including

\footnotetext{
\rceil Entrapment occurs when a body part (e.g., hair, limb, or buttocks) or something on the swimmer's body (e.g., jewelry or bathing suit) becomes caught in the suction of the recirculation pump or in an underwater structure.
} 
design, construction, operation, maintenance, and management. In addition, attendees recommended developing a companion annex to provide the rationale behind the code, including peer-reviewed, scientific data with references. Individual state and local jurisdictions would be free to voluntarily adopt parts of the model code, revise as needed to meet their unique needs before adoption, or choose not to adopt the model code at all.

During 2007-2014, CDC's National Center for Emerging and Zoonotic Infectious Diseases and National Center for Environmental Health (with assistance from the National Center for Injury Prevention and Control and the Public Health Law Office) and the New York State Department of Health spearheaded the development of a model code, now known as the MAHC. Soliciting input from the public health, aquatics, and academic sectors was a cornerstone of this multidisciplinary, multi-stakeholder effort. Fourteen MAHC modules (Box), which included code language and supporting rationale, were drafted by the steering committee or one of 12 technical committees, each with members from the different sectors.

The MAHC steering committee either wrote or reviewed, edited, and approved each draft module in collaboration with the respective technical committee. The 14 modules were posted individually on CDC's MAHC website for a 60-day public comment period. A total of 2,979 comments on the 14 modules were received; $84.1 \%(2,504)$ could be accepted or rejected, of which $76.0 \%(1,904)$ were accepted. A total of 13 modules $\$$ were revised on the basis of public comment, and these revised modules were then interwoven into two documents, the code and the annex, and posted for a second 60-day public comment period. The second public comment period allowed reviewers to cross check among modules and ensure consistency throughout the MAHC. Of 1,428 comments, $92.5 \%(1,321)$ could be accepted or rejected, of which $63.5 \%$ (839) were accepted. Over the two public comment periods, CDC received 4,407 comments and accepted $71.7 \%(2,743 / 3,825)$ of the comments that could be accepted or rejected. Following extensive revision in response to the second public comment period, CDC released the first edition of the MAHC and its annex on August 29, 2014. The MAHC represents the combined work of more than 150 public health, aquatics, and academic volunteers and the many contributors of public comments that helped optimize the MAHC. To keep current with the latest scientific data and aquatics sector innovations, the MAHC will be updated every 2 years through an all-stakeholder-driven process, much like the MAHC development process. The nonprofit organization, the

\footnotetext{
$\$$ The regulatory module ultimately was not included within the MAHC because its content was intended as guidance for state and local environmental health aquatic inspection programs rather than as guidance on the design, construction, operation, maintenance, and management of public aquatics facilities.
}

BOX. Fourteen Model Aquatic Health Code modules

- Contamination burden

- Disinfection and water quality

- Facility design and construction

- Facility maintenance and operation

- Fecal/vomit/blood contamination response

- Hygiene facilities

- Lifeguarding and bather supervision

- Monitoring and testing

- Operator training

- Preface, user guide, and definitions

- Recirculation systems and filtration

- Regulatory

- Risk management/safety

- Ventilation and air quality

Council for the Model Aquatic Health Code (CMAHC; https:// www.cmahc.org/index.php), was created in 2013 and its role is to

- collect, assess, and relay national input on needed MAHC revisions back to CDC for final consideration for acceptance;

- advocate for improved health and safety at public aquatic facilities;

- provide assistance to health departments, boards of health, legislatures, and other partners on MAHC uses, benefits, and implementation;

- provide assistance to the aquatics sector on uses, interpretation, and benefits of the MAHC; and

- solicit, coordinate, and prioritize MAHC research needs.

The CDC-CMAHC partnership should ensure that the MAHC remains up to date and continues to minimize the risk for illness and injury at public aquatic venues. In October 2015, the first CMAHC biennial conference was held. CMAHC members subsequently voted on 159 change requests to help guide CDC's revision of the MAHC prior to the release of its second edition during the 2016 summer swim season.

\section{Tracking Voluntary Adoption of the MAHC}

The MAHC is a comprehensive CDC model code that brings infectious disease and injury epidemiology, environmental health, and public health law expertise together to protect public health at public aquatic facilities. The magnitude of the MAHC's impact on the design, construction, operation, maintenance, and management of U.S. public aquatic facilities is dependent on how many, and which, jurisdictions adopt its recommendations. To track voluntary adoption of the MAHC across the United States, CDC is systematically searching legal databases (e.g., Municode and WestLaw) for changes to public 
health codes for public aquatic facilities in 20 state and local jurisdictions. The jurisdictions were selected because they had either 1) the highest counts of public aquatic venues and the highest drowning rates $(8)$ or 2 ) the most aquatic venues per 100,000 persons (9). The searches prioritize recommendations unique to the MAHC that have the greatest potential impact on public health (e.g., requirements for inactivating Cryptosporidium, fencing 6 feet in height, and training on chemical safety for those who handle pool chemicals). The search criteria also include any direct mention of the MAHC or replicated MAHC text.

\section{References}

1. Buss BF, Safranek TJ, Magri JM, Török TJ, Beach MJ, Foley BP. Association between swimming pool operator certification and reduced pool chemistry violations-Nebraska, 2005-2006. J Environ Health 2009;71:36-40.

2. Johnston K, Kinziger M. Certified operators: does certification provide significant results in real-world pool and spa chemistry? IJARE 2007;1:18-33.
3. CDC. Promotion of healthy swimming after a statewide outbreak of cryptosporidiosis associated with recreational water venues-Utah, 2008-2009. MMWR Morb Mortal Wkly Rep 2012;61:348-52.

4. McClain J, Bernhardt JM, Beach MJ. Assessing parents' perception of children's risk for recreational water illnesses. Emerg Infect Dis 2005;11:670-6. http://dx.doi.org/10.3201/eid1105.040779

5. Beach MJ. Waterborne: recreational water. Cryptosporidium and cryptosporidiosis. 2nd ed. Boca Raton, FL: CRC Press; 2008.

6. Murphy JL, Arrowood MJ, Lu X, Hlavsa MC, Beach MJ, Hill VR. Effect of cyanuric acid on the inactivation of Cryptosporidium parvum under hyperchlorination conditions. Environ Sci Technol 2015;49:7348-55. http://dx.doi.org/10.1021/acs.est.5b00962

7. Shields JM, Hill VR, Arrowood MJ, Beach MJ. Inactivation of Cryptosporidium parvum under chlorinated recreational water conditions. J Water Health 2008;6:513-20. http://dx.doi.org/10.2166/wh.2008.068

8. CDC. Stay safe in and around swimming pools. Atlanta, GA: US Department of Health and Human Services, CDC; 2011. http://www. cdc.gov/Features/dsSafeSwimmingPool

9. Trust for Public Land. 2011 city park facts. San Francisco, CA; 2011. http://cloud.tpl.org/pubs/ccpe-city-park-facts-2011.pdf 



The Morbidity and Mortality Weekly Report (MMWR) Series is prepared by the Centers for Disease Control and Prevention (CDC) and is available free of charge in electronic format. To receive an electronic copy each week, visit MMWR's free subscription page at http://www.cdc.gov/mmwr/mmwrsubscribe.html. Paper copy subscriptions are available through the Superintendent of Documents, U.S. Government Printing Office, Washington, DC 20402; telephone 202-512-1800.

Readers who have difficulty accessing this PDF file may access the HTML file at http://www.cdc.gov/mmwr/volumes/65/ss/ss6501a1.htm?s_cid=ss6501a1_w. Address all inquiries about the $M M W R$ Series, including material to be considered for publication, to Executive Editor, MMWR Series, Mailstop E-90, CDC, 1600 Clifton Rd., N.E., Atlanta, GA 30329-4027 or to mmwrq@cdc.gov.

All material in the MMWR Series is in the public domain and may be used and reprinted without permission; citation as to source, however, is appreciated. Use of trade names and commercial sources is for identification only and does not imply endorsement by the U.S. Department of Health and Human Services.

References to non-CDC sites on the Internet are provided as a service to $M M W R$ readers and do not constitute or imply endorsement of these organizations or their programs by CDC or the U.S. Department of Health and Human Services. CDC is not responsible for the content of these sites. URL addresses listed in $M M W R$ were current as of the date of publication.

ISSN: 1546-0738 (Print) 